\title{
Postoperative Natural Killer Cell Dysfunction: The Prime Suspect in the Case of Metastasis Following Curative Cancer Surgery
}

\author{
Marisa Market ${ }^{1,2}$, Gayashan Tennakoon ${ }^{1}$ and Rebecca C. Auer ${ }^{2,3, *(D)}$ \\ 1 Faculty of Medicine, University of Ottawa, Ottawa, ON K1G 8M5, Canada; mmark030@uottawa.ca (M.M.); \\ gtennakoon@ohri.ca (G.T.) \\ 2 The Ottawa Hospital Research Institute, Ottawa, ON K1G 4E3, Canada \\ 3 Department of General Surgery, The Ottawa Hospital, Ottawa, ON K1Y 4E9, Canada \\ * Correspondence: rauer@ohri.ca; Tel.: +1-613-722-7000
}

Citation: Market, M.; Tennakoon, G.; Auer, R.C. Postoperative Natural Killer Cell Dysfunction: The Prime Suspect in the Case of Metastasis Following Curative Cancer Surgery. Int. J. Mol. Sci. 2021, 22, 11378. https://doi.org/10.3390/ijms222111378

Academic Editors: Haiyoung Jung and Ji-Yoon Noh

Received: 11 September 2021

Accepted: 6 October 2021

Published: 21 October 2021

Publisher's Note: MDPI stays neutral with regard to jurisdictional claims in published maps and institutional affiliations.

Copyright: (c) 2021 by the authors. Licensee MDPI, Basel, Switzerland. This article is an open access article distributed under the terms and conditions of the Creative Commons Attribution (CC BY) license (https:/ / creativecommons.org/licenses/by/ $4.0 /)$.

\begin{abstract}
Surgical resection is the foundation for the curative treatment of solid tumors. However, metastatic recurrence due to the difficulty in eradicating micrometastases remain a feared outcome. Paradoxically, despite the beneficial effects of surgical removal of the primary tumor, the physiological stress resulting from surgical trauma serves to promote cancer recurrence and metastasis. The postoperative environment suppresses critical anti-tumor immune effector cells, including Natural Killer (NK) cells. The literature suggests that NK cells are critical mediators in the formation of metastases immediately following surgery. The following review will highlight the mechanisms that promote the formation of micrometastases by directly or indirectly inducing NK cell suppression following surgery. These include tissue hypoxia, neuroendocrine activation, hypercoagulation, the pro-inflammatory phase, and the anti-inflammatory phase. Perioperative therapeutic strategies designed to prevent or reverse NK cell dysfunction will also be examined for their potential to improve cancer outcomes by preventing surgery-induced metastases.
\end{abstract}

Keywords: surgery; natural killer cells; immune suppression; cellular immunity; cancer

\section{Opening Arguments: A Brief History of Cancer Surgery}

Cancer is one of the leading causes of death in North America, with an estimated 1.9 million new cancer cases and 693,000 cancer deaths in 2018 [1]. Despite advances in detection and treatments, the five-year net survival for people diagnosed with cancer in Canada is 60\% [2]. Historically, the treatment of cancer has long been a medical challenge, as has been recorded in the earliest chronologies of human existence. Although the word "cancer" was not used, the oldest description of this disease can be found in the Edwin Smith Papyrus, an ancient Egyptian text that dates back to 3000-2500 B.C [3-5]. The text describes breast tumors that were surgically removed using primitive tools, such as the "fire drill" $[4,5]$. These treatments proved futile and this record concludes that "there is no cure" $[4,6]$. Surgery continued to be provided as a largely unsuccessful treatment for a variety of cancers, until the development of anesthesia in 1846 radically changed the field of surgery, allowing for longer, more complex surgeries [7]. In 1890, William Halsted developed the Halstedian model for cancer progression and proposed that cancer (specifically breast cancer), spreads through the lymphatic system. This resulted in a strong emphasis on aggressive locoregional treatment in an attempt to avoid cancer recurrence $[8,9]$. There was a rapid development of cancer surgery techniques, ranging from abdominoperineal resection to pneumonectomy, to radical hysterectomy, and radical suprapubic prostatectomy, in the early 20th century $[8,10]$. Halstedian surgical techniques were later shown to provide little benefit over less invasive procedures and have since been replaced by less radical procedures that have significantly improved patient quality of life $[8,11,12]$. Today, 
surgery provides undeniable benefits to cancer patients, as complete surgical resection is curative in the majority of patients [13-15]. Additionally, the removal of the primary tumor relieves the mass effect, prevents the release of tumor-associated factors, and allows for pathological assessment of the cancer to inform treatment [16]. In addition to surgery, the evolution of radiotherapy and chemotherapy continued into the late 20th century and remain critical pillars in the treatment of solid cancer today [8]. However, despite the advancements in cancer treatment, recurrence rates have plateaued, due mostly to our inability to effectively eradicate micrometastases $[8,10]$. Unfortunately, in too many cases, surgery is either too much, such as with Halstedian surgical techniques, or too little, where no amount of surgery would have been curative due to metastatic disease. What the Roman physician Celsus wrote in $100 \mathrm{BC}$ still holds true: "After excision, even when a scar has formed, none the less the disease has returned" [17].

\section{The Crime: Surgery and Metastasis Formation}

Paradoxically, in contrast with the curative potential of surgery, surgical resection has long been linked to increased metastases and cancer recurrence [18]. This link was first made more than a century ago in the 1910s when Marie and Clunet found that incomplete excision of implanted tumors resulted in increased rates of metastasis [19]. Similar studies were performed by Tyzzer [20], who ultimately atttibuted this phenomenon to the "athrepsia hypothesis", whereby tumor proliferation was dependent upon competition for host-derived nutrients [21]. By the mid-20th century, more modern hypotheses on cancer growth and metastasis developed, leading to the concept of the "dormant" cancer cell: cancer cells that remain quiescent while still retaining their ability to proliferate [22]. Various investigators wrote about animal models in which dormant tumor cells could be triggered to grow by some unknown mechanism in response to surgery $[18,23]$. Over half a century later, the question still remains: What are these mechanisms? Several hypotheses include tissue hypoxia, neuroendocrine activation, hypercoagulation, the initial pro-inflammatory phase, and the subsequent anti-inflammatory phase (shown in Figure 1). Ultimately however, the end result is a negative effect on immune effector cell function, culminating in suppressed cellular immunity. As outlined in the section below, Natural Killer (NK) cells are critical to the anti-tumor response, and thus, their postoperative dysfunction is the prime suspect in the case of pardoxical postoperative metastases [24,25]. 


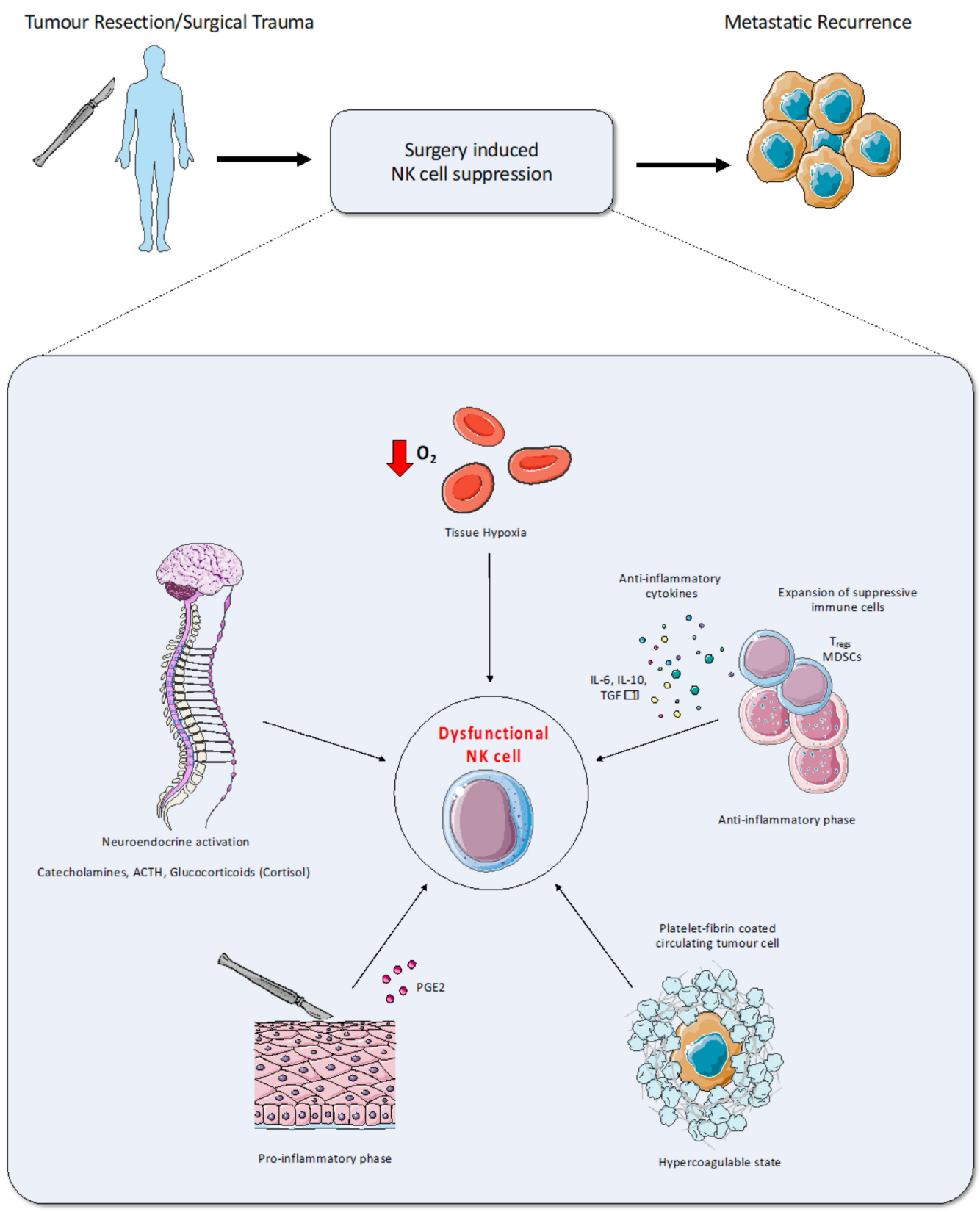

Figure 1. Potential mechanisms of postoperative cancer recurrence. Numerous changes occurring in the postoperative period have been hypothesized to be responsible for NK cell suppression and postoperative metastasis. These include tissue hypoxia, neuroendocrine activation, a pro-inflammatory phase, a hypercoagulable state, and an anti-inflammatory phase characterized by the release of anti-inflammatory cytokines and the expansion of immunosuppression populations in addition to cellular immune suppression.

\section{On Trial: Natural Killer Cells as Potent Tumor Killers}

Natural Killer (NK) cells, first identified by Kiessling et al., in 1975, are cytotoxic lymphocytes that play a critical role in the innate immune response by destroying circulating stressed, infected, or cancerous cells [26-28]. Mature NK cells can be divided into two functional subsets based on the cell surface density of CD56 and the low-affinity Fc-receptor CD16 [29,30]. CD56 ${ }^{\mathrm{dim}} \mathrm{CD} 16^{+} \mathrm{NK}$ cells make up $90 \%$ of peripheral blood and splenic NK cells and are preferentially cytotoxic, whereas most lymph node NK cells are $\mathrm{CD} 56^{\text {bright }} \mathrm{CD} 16^{\mathrm{dim} /-}$ and readily produce cytokines $[29,30]$. While NK cells do not undergo clonal selection, they instead express a limited number of germline-encoded receptors [31]. 
NK cell activity is regulated by the integration of activating and inhibitory ligands through these receptors [31,32]. NK cell activating receptors recognize pathogen-derived antigens as well as stress-induced ligands in what is termed the "induced-self recognition model" [33] and include Natural Cytotoxicity Receptors (NCRs; NKp30, NKp44, NKp46, and NKp80) and the C-type lectin-like receptors NKG2D and CD94-NKG2C [34,35]. In addition to these activating receptors, co-activating receptors, for example DNAX-accessory molecule (DNAM-1, CD226), serve to fine-tune NK cell activity [36-38]. These activating signals are antagonized by inhibitory receptors, including Killer Immunoglobulin-like Receptors (KIRs) and C-type lectin-like receptor CD94-NKG2A [30,39], which recognize constitutively expressed self-molecules. Natural Killers must also integrate signals from activating and inhibitory cytokines. IL-2, IL-12, IL-15, and IL-18 [40,41] positively regulate NK cell function, while IL-10 [42-50] and IL-6 [51-55] have pleiotropic effects. Transforming growth factor- $\beta$ (TGF $\beta$ ) is predominantly anti-inflammatory and is critical for maintaining homeostasis and preventing autoimmunity [56,57].

NK cells mobilized for the immune response induce apoptosis via death receptor ligands such as FasL and TRAIL [58], undergo $\mathrm{Ca}^{2+}$-dependent exocytosis of cytolytic granules (perforin and granzymes) [33,34], and secrete numerous cytokines, including interferon-gamma (IFN $\gamma)$, tumor necrosis factor-alpha (TNF $\alpha)$, and granulocyte monocytecolony stimulating factor (GM-CSF), which serve to modulate the immune response [33,59]. Finally, NK cells also participate in antibody-dependent cell-mediated cytotoxicity (ADCC) through CD16 [60].

The functional features of NK cells perfectly position them as natural cancer killers with the ability to respond to tumor cells in the absence of immunological priming. For example, numerous induced self-ligands are upregulated during oncogenic transformation, including NKG2D ligands MICA/B and ULBP1-6 [61] and DNAM-1 ligands CD155 and CD112 [62]. Death receptors, including TRAIL-R1/2, are also widely expressed on tumor cells $[63,64]$. Furthermore, tumor cells downregulate HLA Class I ("self" molecules) in an attempt to escape T cell mediated responses [65], simultaneously releasing the inhibitory "break" on NK cells. By tipping the balance towards activation, NK cells are then able to directly kill cancer cells (via death receptors and cytotoxic granules) and to rally other immune cells to do the same (via immunomodulatory cytokines).

Importantly, circulating NK cell function is correlated with clinical cancer outcomes in both solid and hematological malignancies [66]. In human studies, higher NK cell activity is inversely correlated with cancer risk [67-70] and reduced NK cell activity [71-74] is associated with a worse cancer prognosis in numerous cancer types. An 11-year prospective cohort study among 154 Japanese patients assessed the association between PBMC cytotoxic activity at baseline and cancer incidence. They found that both men and women with medium and high cytotoxicity activity had a reduced cancer risk, while low cytotoxic activity was associated with an increased cancer risk, suggesting a role for immune cell cytotoxicity in the prevention of cancer [68]. In patients with colorectal cancer (CRC), an increased number of NK cells was an independent predictor of improved survival [75]. Additionally, several studies have reported that high levels of NK cell activating receptors (CD56, CD57, NKp30, NKG2D, and NKp46) as well as granzyme B were significantly correlated with better overall survival (OS) in patients with a variety of solid malignancies [25,67,71,76-80]. Inhibition of NK cell-dervied IFN $\gamma$ was associated with higher stage gastric cancers and worse clinicopathological parameters including tumor size, depth of invasion, and lymph node metastasis [81]. In murine metastasis models, NK cell depletion and genetic deficiency of IFN $\gamma$ or perforin results in increased metastasis [66]. Taken together, this suggests that immune cell, and specifically NK cell, function is critical for the prevention of tumorigenesis.

Tumor cells can employ a plethora of mechanisms to induce NK cell dysfunction, including upregulation of immune checkpoint expression, such as PD-1, prolonged exposure to MHC class 1-deficient tumor cells and/or NK cell activating receptor antagonists [82,83], the secretion of tumor cell-derived exosomes [84], as well as the secretion of inhibitory tumor-derived cytokines, such as IL-10 and TGF $\beta 1[66,85,86]$. In addition, tumor cells 
employ a variety of mechanisms to down-modulate surface activating receptors such as NKG2D [83]. This leads to alterations in the homeostatic balance of these receptors resulting in dysfunctional NK cell cytotoxicity and cytokine secretion. Thus, despite their innate ability to recognize and target tumor cells, NK cell function can be suppressed by tumor cells.

\section{Making a Case for Natural Killer Cell Suppression as the Underlying Driver of Postoperative Metastasis}

Cellular immune suppression is a universal response to the pathways that are activated in response to surgery. Surgical stress has been shown to cause a decrease in circulating dendritic cells (DCs), and significant dysfunction in T cells and NK cells [24,25,87-92]. As outlined above, NK cells play a central role in the early formation and erradication of metastases. For this reason, postoperative NK cell suppression has been investigated as the mechanism responsible for cancer recurrence post-curative surgery.

The literature presents significant evidence to incriminate NK cell dysfunction in the early formation of postoperative metastases. Numerous investigators have established a link between the suppression of NK cell cytotoxicity in the postoperative period and increased metastatic formation in animal models $[24,93,94]$. Our lab has developed a reproducible mouse model of surgical stress [24,95], whereby DX5 ${ }^{+}$splenic NK cells were isolated from surgically stressed and naïve mice and adoptively transferred into pharmacologically NK cell-depleted tumor-challenged mice. Mice that had received surgically stressed NK cells had significantly increased lung tumor burden compared to mice that had received NK cells from controls [24]. Moreover, adoptive transfer of non-NK immune cells in a similar manner resulted in no signifincant difference in tumor burden between the two groups, highlighting the specific role of surgical stress in impacting NK cell function to induce metastasis. Moreover, animals receiving anesthesia $(0.05 \mathrm{mg} / \mathrm{kg}$ buprenorphine) alone had similar metastatic burden to control mice, suggesting that the pro-metastatic effect seen postoperatively is anesthesia/analgesia-independent [24,95]. These experiments established NK cells as the critical effector cells responsible for mediating postoperative metastasis.

In human studies, reduced NK cell activity is associated with increased rates of cancer recurrence and death [96-98]. Iannone et al., studied NK cells in pancreatic cancer surgery patients and found a significant decrease in cytotoxicity on POD7, which was restored by POD30 [89]. Velásquez et al., also reported that NK cell in vitro killing of K562 leukemia cells was suppressed up to five days after surgery in patients with primary bone cancer [90]. We have recently shown that postoperative NK cells from CRC surgery patients have suppressed in vitro cytotoxic killing of tumor cells (K562 leukemic cells), which was most profoundly reduced on POD1 and returned to baseline levels by POD28. Postoperative samples also had reduced IFN $\gamma$ production in response to cytokine stimulation using $\mathrm{NKVue}^{\mathrm{TM}}$ [25]. The most profound suppression was observed on POD1 where we saw $90.2 \%$ (37/41) of patients had IFN $\gamma$ levels below the minimum detectable level $(15.6 \mathrm{pg} / \mathrm{mL})$. As compared to baseline, the mean reduction in IFN $\gamma$ production was $83.1 \%$ (s.d. 25.2\%; CI: 75-91). Astoundingly, this suppression persisted until POD28 in 65.5\% $(19 / 29)$ of patients and POD56 in 33.3\% (4/12) of patients [25]. Additionally, Reinhardt et al., investigated IFN $\gamma$ production in response to Staphylococcus aureus or IL-12 stimulation in the CD56 $6^{\text {Bright }}$ population of surgery patients and found a significant decrease in IL-12R (CD212) expression and an impairment in IFN $\gamma$ production on POD1 up to 7 days postoperatively [91].

\section{The Evidence: Understanding the Mechanisms of Postoperative Natural Killer Cell Suppression}

There is strong evidence in murine models and in cancer patients that NK cell dysfunction is responsible for the development of postoperative metastases. The cause (s) of NK cell suppression is currently unknown, although there are numerous hypothesized 
mechanisms of postoperative metastases, many of which directly or indirectly contribute to NK cell suppression. These mechanisms are discussed below.

\subsection{Exhibit A: Physiologic Responses to Surgical Stress}

\subsubsection{Tissue Hypoxia Directly Impairs NK Cell Cytotoxicity while Tumor Cells Thrive}

Hypoxia describes a state of reduced oxygen supply and is a common and persistent consequence of surgery [99-102]. Hypoxia can directly impair NK cell function via Hypoxia-Inducible Factor (HIF) $1 \alpha$ pathway activation, which leads to alteration of the transcriptome, modification of metabolism gene expression, proinflammatory cytokine and chemokine secretion, as well as an impairment in the release of IFN $\gamma, \mathrm{TNF} \alpha, \mathrm{GM}-\mathrm{CSF}$, and CCL3 [103,104]. Balsamo et al., cultured NK cells isolated from healthy donor PBMCs under hypoxic (1\% oxygen) or normoxic ( $20 \%$ oxygen) conditions. They reported that hypoxia caused a downregulation of surface markers NKp46, NKp30, NKp44, and NKG2D, independent of the presence of IL-2, IL-15, IL-12, or IL-21. Hypoxic NK cells also exhibited lower cytotoxicity against FO-1 melanoma cells due to impaired degranulation [105]. Recent investigations have revealed that hypoxia in NK cells induces the activity of protein tyrosine phosphatase SHP-1 (Src homology region 2 domain-containing phosphatase-1), which attentuates STAT3 and ERK signalling leading to an impairment of NK cell function [106]. Moreover, tumor cells have evolved to use hypoxic stress to their advantage through HIF activation $[107,108]$, resulting in immune suppression and tolerance to immune surveillance by promoting MDSC accumulation, inhibiting DC maturation, and recruiting $T_{\text {regs, }}$ which ultimately impair NK cell function $[104,108,109]$. Through these mechanisms of NK cell impairment, hypoxia as a result of surgery and in the context of cancer may therefore play a critical role in postoperative metastases and cancer recurrence [110,111].

Interestingly, despite studies reporting NK cell impairment in response to cytokine stimulation in the context of hypoxia, pre-activation of NK cells with IL-2 was able to abrogate this functional suppression. Importantly, pre-activated NK cells maintained NKG2D expression and could mediate cytoxic killing of multiple myeloma (MM) cells, even under hypoxic conditions [112]. Solocinski et al., demonstrated that genetically-engineered "highaffinity" NK cells (haNKs), which express a high affinity CD16 receptor and endogenous IL-2, were resistant to hypoxia-induced functional suppression. Compared to normal NK cells, which exhibited reduced cytotoxity against PC3, MCF-7, and H460 cell lines, haNK cells maintained high cytoxicity against target cells under hypoxic conditions [113]. Taken together, preoperative adminstration of IL-2 could be a viable therapeutic strategy to prevent postoperative hypoxia-induced functional suppression of NK cells (Table 1). However, this has not yet been explored in the context of a clinical trial with potential adverse effects including increased risk of hypercytokinemia and systemic inflammation [114,115].

Table 1. Potential therapeutics to target postoperative Natural Killer cell suppression.

\begin{tabular}{cccc}
\hline Mechanism & Potential Target & Potential Therapies & $\begin{array}{c}\text { Potential Adverse Surgical } \\
\text { Effects }\end{array}$ \\
\hline Tissue Hypoxia & NK cells & $\begin{array}{c}\text { Preoperative IL-2 } \\
\text { adminsitration } \\
\text { Autologous genetic } \\
\text { engineering of NK cells to } \\
\text { produce IL-2 endogenously }\end{array}$ & $\begin{array}{c}\text { Increased risk of systemic } \\
\text { inflammation and } \\
\text { hypercytokinemia }\end{array}$ \\
\hline Neurendocrine activation & B-adergenic receptor & Propranolol & $\begin{array}{c}\text { Cardiopulmonary effects } \\
\text { Severe hypokalemia, } \\
\text { hypertension, and adrenal } \\
\text { insufficiency }\end{array}$ \\
\hline Hypercoagulable state & Glucocorticoid receptor & Mifepristone & $\begin{array}{c}\text { Thrombocytopenia, leading to } \\
\text { increased risk of internal } \\
\text { bleeding }\end{array}$ \\
\hline
\end{tabular}


Table 1. Cont.

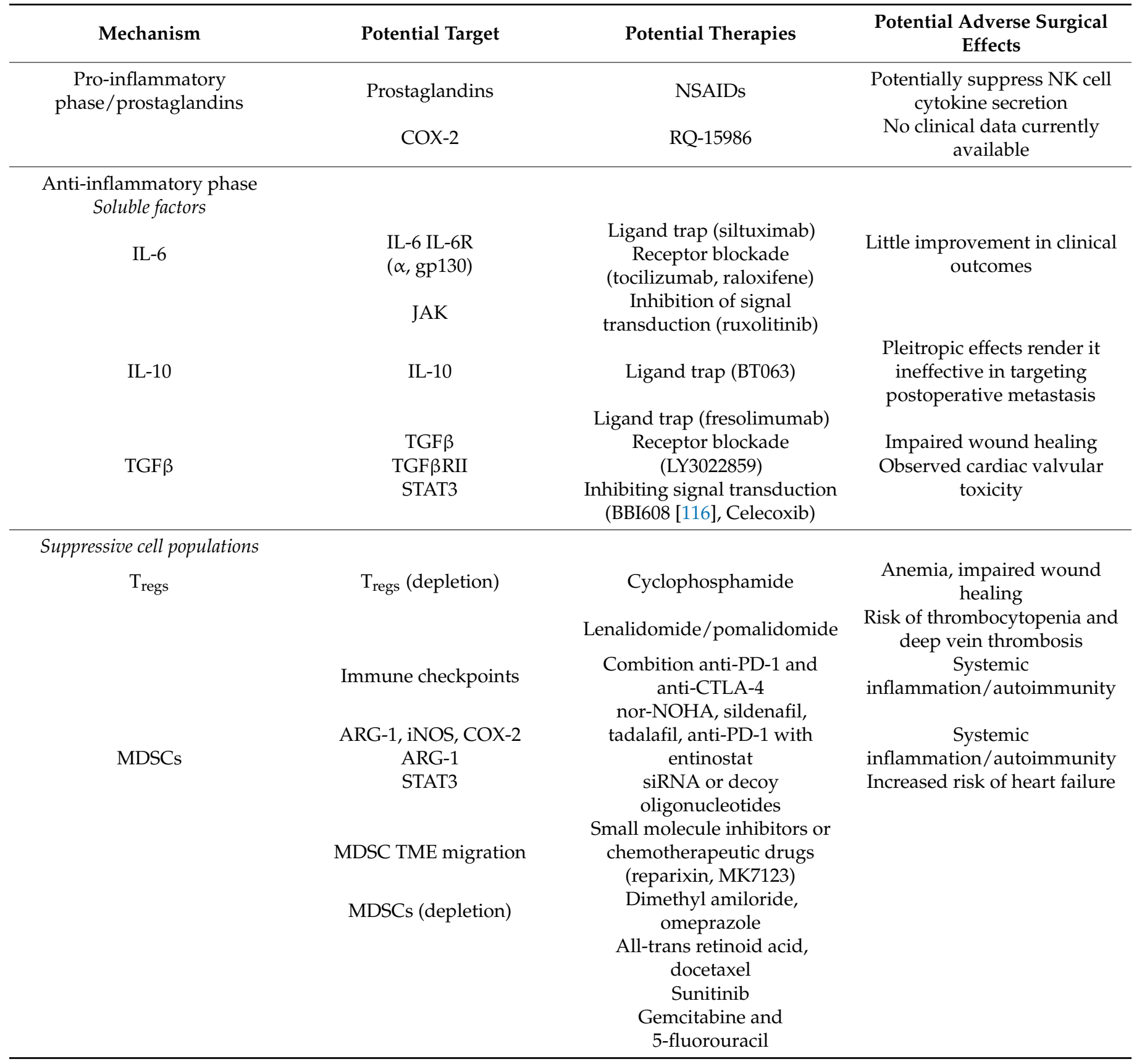

\subsubsection{Hypothalamic-Pituitary-Adrenal Axis Activation Alters NK Cell Epigenetics}

Initially described in response to injury or trauma, the "stress response" is a series of complex physiological events that include neuroendocrine and hypothalamic-pituitaryadrenal (HPA) axis activation $[117,118]$. The subsequent sympathetic autonomic nervous system activation then results in the release of catecholamines from the adrenal medulla and norepinephrine from presynaptic nerve terminals leading to the activation of adrenergic receptors [118]. In addition, corticotrophin (ACTH) released by the pituitary stimulates the adrenal cortex to release glucocorticoids (GCs), including the stress hormone cortisol, into the bloodstream. Surgery is one of the most potent activators of ACTH/GCs and inhibits the physiologic negative feedback mechanism, resulting in increasing plasma levels of these hormones [117]. HPA activation has complex metabolic effects that are evolutionarily 
essential for survival post-trauma, although it has been argued that this response to sterile surgery is unnecessary.

Chronic activation of the sympathetic system through stress or pharmological means has been shown to reduce NK cell activty $[119,120]$. In a rat model of MADB106 mammary adenocarcinoma lung metastasis, psychological stress or adminsitration of metaproterenol, a non-selective $\beta$-adrenergic agonist, was shown to reduce NK cell activity resulting in increased metastatic burden [121,122]. $\beta$-adrenergic receptor activation resulted in fewer NK cells in the lungs and reduced NK cell cytoxicity against MADB106 cells in vitro $[117,123]$. GCs are also considred to be anti-inflammatory, as they can inhibit the expression of proinflammatory cytokines, such as IL-6, TNF, IL-1 $\beta$, or IL-12, from monocytes, macrophages, and DCs [124]. Furthermore, GCs have also long been known to inhibit NK cell activity. GCs were shown to alter the expression of surface receptors critical for NK cell functions, including CD16, DNAM-1, NKp46 and NKp30 [125,126]. Treatment of isolated NK cells with the synthetic GC dexamethosone was shown to inhibit mTORC1 leading to reduced IFN $\gamma$ production following IL-2/IL-12 sitmulation [126]. In addition, GCs have been shown to impair NK cell cytoxiticty as evidenced by reduced perforin and granzyme A/B release $[124,127,128]$. These immunosuppressive effects are thought to be mediated via epigenetic changes. Treatment of NK cells with dexamethosone was shown to cause a signifcant reduction of $\mathrm{H} 4-\mathrm{K} 8$ acetylation in the IFN $\gamma$ and perforin promoters. Moreoever, this effect was abrogated by Trichostatin A, a histone deacetylase inhibitor. This suggests that GCs reduce promoter accessibility, thereby reducing expression of NK cell effector molecules. In fact, treatment of NK cells with TSA abrogated GC-induced reduction of IFN $\gamma$ secretion $[128,129]$.

Current research has focused on targeting adrenergic receptors using $\beta$-blockers with promising results showing improved NK cell function along with reduced invasive potential and tumor growth in vitro and reduced cancer recurrence or severity in cancer patients $[117,118,130]$ (Table 1). In addition, a Phase 2 randomized trial of perioperative propranolol, a $\beta$-blocker, and etolodac in breast cancer patients reported normalization of IL-6 and CRP, decreased EMT, and decreased tumor-infiltrating monocytes [131]. A multi-centre Phase 3 clinical trial to assess immune suppression and cancer recurrence in CRC surgery patients treated with propranolol and etolodac is currently underway (NCT00888767) [132]. Importantly, the cardiopulmonary effects of $\beta$-blockers must be considered in the perioperative period. As of yet, there are no therapeutics targeting surgery-induced upregulation of glucocorticoids. However, hypercortosolism can be treated with mifepristone (RU486), the only glucocorticoid receptor (GR) antagonist that is availabe for clinical use [129] (Table 1). In two sutdies, Chen et al., demonstrated that isolated human uterine as well as peripheral blood NK cells showed increased cytoxicity against K562s in the presence of mifepristone, aborgating the immunosuppressive effects of cortisol exposure $[133,134]$. Morever, mice that underwent LPS-induced immunosuppression had restored humoural and T-cell anti-tumor responses as well as improved tumor clearance when treated with mifepristone (30 mg/kg; i.p.) [135]. Finally, mifepristone signficantly increased the one year surval rate of spontaneous lung cancer in a murine model [136]. Taken together, this illustrates that mifepristone can antagonize glucocorticoid-mediated immune suppression, thereby improving tumor clearance. As a result, administration of mifepristone could be a viable perioperative treatment to address the role of glucocorticoids in mediating postoperative immunosuppresion. Potential side effects of mifepristone use include hypokalemia, hypertension, and adrenal insufficiency $[137,138]$.

5.1.3. The Postoperative Hypercoagulable State Shields Tumor Cells from NK-Mediated Clearance

Surgery and cancer independently have been associated with a hypercoagulable state. This is characterized by increased tissue factor, fibrin, and thrombin, platelet activation, and the formation of clots around tumor cell emboli and circulating tumor cells (CTCs) $[95,139]$. These clots may facilitate micrometastases, tumor cell adherence to endothelial cells [95] and importantly, immune evasion. CTCs, which are critical for the formation of distant micrometastases, can be coated by platelets and firbin, resulting in physical protection from NK cells in the 
blood stream [140]. Nieswandt et al., demonstrated that the presence of platelets protected Yac1 cells from NK cell cytotoxicity in vitro. Blocking platelet aggregation using hirudin, heparin, ADP scavenger apyrase, and anti-P-selectin mAbs reversed the platelet-mediated protection by inhibiting platelet aggregation [141]. This platelet coating can also secrete TGF $\beta$, which inhibits NK cell cytoxicity by impairing granule mobilization and IFN $\gamma$ secretion [142]. Placke et al., reported that co-culture of MHC I negative NCCIT cancer cells with a thousandfold excess of platelets led to membrane protein transfer resulting in the expression of platelet-derived MHC I molecules on the cancer cells. Consequently, this acquired "pseudoself" phenotype countered the "missing self" mechanisms critical to NK cell anti-tumor cytotoxicity, leading to reduced killing of cancer cells compared to controls [143,144]. Taken together, there are numerous mechanisms by which a hypercoagulable state resulting in platelet-fibrin clots may subvert NK cell-mediated tumor cell clearance.

Interestingly in murine studies, platelet depletion and P-selectin deficiency were shown to reduce experimental metastases and fibrinogen-deficient mice demonstrated significantly reduced implanted and spontaneous metastatic foci [145-150]. Clinically, perioperative anticoagulation has been associated with increased cancer-specific survival in cancer surgery patients [151-153]. Seth et al., investigated the role of surgery-induced hypercoagulation on metastases in a murine model and found that treatment with low molecular weight heparin (LMWH) was able to reduce metastases through the inhibition of peritumoral clot formation [95] (Table 1). Furthermore, this effect was NK cell-mediated in that LMWH was unable to attenuate metastasis in NK cell-depleted surgically stressed mice [95]. The ability of LMWH to reduce metastases and increase survival has been documented in both murine models and patients with solid malignancies [151,152,154-156]. For these reasons, our group is conducting a Phase 3 clinical trial in which perioperative LMWH is given to CRC surgery patients in an effort to reduce postoperative metastasis (PERIOP-01; NCT01455831) [157,158]. Regardless of the context, the use of LMWH carriers the risk of thrombocytopenia and internal bleeding $[159,160]$.

\subsection{Exhibit B: Immune-Mediated Responses to Surgical Stress}

5.2.1. Pro-Inflammatory Prostaglandins Increase Tumorgenicity and Suppress NK Cell Function

Despite advancements in surgical technique, injury to healthy tissue is unavoidable, resulting in an acute inflammatory response mediated by soluble factors [110]. While necessary for wound healing, these soluble factors also stimulate cancer cell proliferation and migration. When combined with disrupted endothelium, this constitutes an ideal condition for CTC seeding after surgery [161]. One such factor is the COX-2 product prostaglandin E2 (PGE2), which can be both released by tumor cells [130] and act directly on tumor cells to induce metastatic activity, proliferation, adhesion, migration, extracellular matrix invasion, resistance to apoptosis, and the secretion of proangiogenic factors [130]. Interestingly, in cancer patients, PGE2 is associated with increased tumor size and stage, recurrence, and decreased OS [130]. In the postoperative period, PGE2 was shown to be elevated from hours 9 through 30 postoperatively in the CSF and at the surgical site of osteoarthritis patients undergoing primary total hip arthroplasty [162]. Furthermore, using a rat tumor metastasis model, Yakar et al., reported that exogenous PGE2 resulted in a dosedependent increase in MADB106 lung tumor retention and dose-dependent suppression of NK cell activity. Additionally, selective depletion of NK cells abrogated PGE2-mediated lung tumor retention [163], suggesting a role for PGE2-dependent suppression of NK cells and postoperative metastasis. In fact, PGE2 is known to suppress NK cell effector functions directly through four endogenous PGE2 receptors, EP1-4 [164,165], and indirectly via the downregulation of the common $\gamma$ chain receptor subunit [166].

In terms of potential therapeutics, COX-2 inhibitors (i.e., non-steroidal anti-inflammatory drugs (NSAIDs)) prevent the synthesis of prostaglandins and have been studied as long-term chemopreventers of malignancy due to their ability to increase tumor cell apoptosis, decrease proangiogenic agents, and reduce tumor microvascular density [167-169] (Table 1). However, NSAIDs have also been shown to suppress NK cell cytokine secretion in a COX-independent 
manner [170] and are therefore unlikely to be of use to prevent NK cell suppression in the postoperative period. The small molecule inhibitor RQ-15986 has been shown to block EP4mediated NK cell suppression and inhibit growth of implanted tumor cells and lung metastases in a murine model of breast cancer in vivo [165]. Thus, RQ-15986 may prove to be a viable therapeutic to combat surgery-induced NK cell suppression and metastasis.

\subsubsection{The Compensatory Anti-Inflammatory Phase as the Scene of the Crime}

The prolonged postoperative anti-inflammatory phase was first described by Bone et al., in 1997 as "compensatory anti-inflammatory response syndrome" (CARS) in the context of sepsis [171]. They described a compensatory reaction that could be as great or greater than the initial pro-inflammatory response, the purpose of which was to restore homeostasis [171]. It is now understood that there are overlapping concurrent pro- and anti-inflammatory responses throughout the postoperative period. The extent of surgical trauma is reflected in the degree of inflammatory cytokine production, which in turn has been shown to determine the degree and duration of the subsequent anti-inflammatory sequelae [172]. Hence, the evolutionary motive for postoperative NK cell dysfunction is the achievement of homeostasis. Thus, it may be necessary to mediate both pro- and anti-inflammatory postoperative reponses. The anti-inflammatory phase is characterized by the release of anti-inflammatory cytokines as well as the expansion of immunosuppressive populations.

\section{Increased Secretion of Inhibitory Soluble Factors: Hostile Witnesses? \\ 6.1. Interleukin-6}

IL-6 was initially identified as a B cell stimulatory factor and is produced by monocytes, macrophages, and T cells, as well as non-immune cells [55]. It plays a critical role in inflammation by promoting plasma cell differentiation and antibody production [173], inhibiting regulatory $\mathrm{T}$ cell $\left(\mathrm{T}_{\text {reg }}\right)$ formation, inducing the differentiation of helper $\mathrm{T}\left(\mathrm{T}_{\mathrm{h}}\right)$ 17 cells [174], and promoting cytotoxic T lymphocyte (CTL) differentiation [55]. The IL-6 receptor consists of two subunits: IL-6R $\alpha$ (gp80, CD126) and IL-6R $\beta$ (gp130, CD130) and signaling can occur via classical signaling (initiated by ligation with membrane-bound IL$6 \mathrm{R} \alpha$ ) or trans-signaling via soluble IL-6R $\alpha$ [174]. Regardless of initial pathway activation, IL-6 signal transduction occurs via the activation of many intracellular pathways including: Jak1/TYK2 and downstream STAT1, 3, and 5, the PI3K/Akt pathway, the MAPK pathway, and the MEK-extracellular receptor kinase (ERK) 5 pathway $[55,174,175]$.

IL-6 is known to induce the "acute phase response", characterized by the production of liver proteins such as C-reactive protein (CRP), $\alpha_{2}$ microglobulin, and other proteinases. Postoperatively, IL-6 increases within 30-60 min of tissue damage, peaks at $24 \mathrm{~h}$, and remains high for $72 \mathrm{~h}$ post-trauma. In addition, the magnitude of IL- 6 production reflects the degree of tissue damage $[117,176,177]$. Narita et al., compared postoperative serum cytokine levels in patients with prostate cancer undergoing laparoscopic $(n=66)$ vs. open radical prostatectomy $(n=99)$. They found that IL-6 and CRP levels increased immediately postoepratively in both groups, but were significantly lower in the laparoscopic group on POD1. Clinicaly, postoperative IL-6 and CRP are known to be useful markers of postoperative morbidity, including infection, in cancer and non-cancer patients. In 1992, Oka et al., first reported a relationship between postoperative serum IL-6 levels $>400 \mathrm{pg} / \mathrm{mL}$ and the incidence of postoperative complications in cancer surgery patients [178]. These findings of increased postoperative complications in both cancer and non-cancer surgery patients have been supported by numerous other studies to date [179-181], which is why IL-6 is often used as an indicator of surgical stress. IL-6 also serves as the switch between pro- and anti-inflammatory phases by inducing anti-inflammatory factors including glucocorticoids, soluble TNF $\alpha$ receptors, PGE2-dependent IL-10, arginase-1 (ARG1) expression in MDSCs, and TGF $\beta 1$ [172,182]. The dual pro- and anti-inflammatory effects of IL-6 are thought to be partially mediated by differences in classical signalling versus trans-signalling [176,183,184]. 
Although there is a paucity of research into the effects of IL-6 on NK cell function, IL-6 is reported to be a potent inhibitor of NK cell cytotoxicity. Cifaldi et al., reported reduced expression of perforin and granzyme B in human peripheral NK cells exposed to rIL-6 [52]. Furthermore, the addition of soluble IL-6R or the IL-6R mAb tocilizumab in vitro restored perforin and granzyme B expression [52]. NK cell cytotoxicity was reduced in patients with heart failure and this corelated with increased levels of IL-6 produced by unstimulated PBMCs [53]. Kang and colleagues examined NK cell function in the context of endometriosis and found that IL-6 in peritoneal fluid was able to suppress NK cell differentiation and cytotoxicity via the adapter protein tyrosine phosphatase SHP-2 [54,55]. In the context of cancer, Scheid et al., showed that NK cells isolated from 20 patients with advanced colon and pancreatic cancer had a $50 \%$ reduction in cytotoxicity on day 7 after treatment with rIL-6, which was reproduced with an additional exposure to rIL-6 at day 22 [185]. Furthermore, increased levels of IL-6 were correlated with poorer prognosis in many cancer types, including breast cancer, prostate cancer, metastatic CRC, MM, and non-small cell lung cancer (NSCL] [184,186-190]. Taken together, these studies suggest an inhibitory role for IL-6 in the context of NK cell function.

In the context of metastatic cancer, there are currently over 200 clinical trials investigating the safety and efficacy of various therapeutics targeting the IL-6 pathway, including IL-6 direct inhibitors (i.e., Siltuximab), IL-6R $\alpha$ direct inhibitors (i.e., Tocilizumab), IL-6R gp130 direct inhibitors (i.e., Raloxifene), and JAK inhibitors (i.e., Ruxolitinib) (Clinical Trials Registry, www.clinicaltrials.gov, accessed date: 21 May 2021) (Table 1). Studies to date show mixed results with the majority of therapeutics being well-tolerated but ineffective $[184,191,192]$. This is perhaps due to the dual pro- and anti-inflammatory effects of IL-6 [176,183,184]. Specifically, siltuximab monotherapy has been shown to be well tolerated with no improvement in clinical outcomes in patients with ovarian, pancreatic, CRC, head and neck, and prostate cancers, NSCLC, MM, and renal cell carcinoma [193-197]. In the context of surgery, IL-6 has been shown to play an important role in wound healing [198,199]. Hence, anti-IL-6 therapeutics may impair postoperative healing. However, one study by Locci et al., assessed postoperative wound healing and complications in patients with rheumatoid arthritis taking Tocilizumab (IL-6R $\alpha$ direct inhibitor). The mean delay between Tocilizumab therapy and surgery was 4.94 weeks with 38 patients stopping Tocilizumab less than 4 weeks before surgery. They found that only $8.9 \%$ of patients experienced postoperative complications and concluded that Tocilizumab was not associated with increased rates of postoperative complications [200]. Thus, while provocative, blocking IL-6 might have unintended negative consequences in the context of oncologic surgery, suggesting that it may be more appropriate to target postoeprative NK cell function directly.

\subsection{Interleukin-10}

IL-10 is a critical immunoregulatory cytokine produced by T cells, B cells, NK cells, macrophages, and DCs [57]. Historically, it has been described both as "cytokine synthesis inhibitory factor" (CSIF) due to its role as an inhibitor of $T_{h} 1$ activation and cytokine secretion [57], and as "B cell-derived T cell growth factor" (B-TCGF) due to its ability to stimulate $\mathrm{CD}^{+} \mathrm{T}$ cells [201]. IL-10 has since been reported to also inhibit macrophage cytokine and chemokine secretion, CTL CD28 expression and cytokine production, and $\mathrm{T}_{\mathrm{h}} 1$ proliferation as well as to antagonize DC activity [43,49]. IL-10 is thus essential for the prevention of autoimmunity.

While still widely regarded as a predominantly anti-inflammatory cytokine, IL-10 has recently been shown to have pleiotropic effects on NK cells: inducing in vitro NK cell cytotoxicity [42-48] while inhibiting cytokine production, including IFN $\gamma$ and TNF $\alpha[49,50]$. The IL-10 receptor is composed of two subunits: IL-10R1 and IL-10R2. In NK cells, IL-10 ligation with its receptor has been shown to activate JAK1 and non-receptor tyrosine kinase 2 (TYK2), resulting in the phosphorylation and activation of STAT1, 3, and 5 [57]. The exact pathways by which IL-10 exerts activating versus inhibitory effects on NK cells require 
further investigation and may be influenced by the activity of other immune cells, as well as the cytokine milieu.

IL-10 has also been shown to increase significantly following surgical stress [202-204]. In the context of major abdominal surgery, both IL-10 mRNA and serum IL-10 were shown to be increased on POD1 [203]. Kato and colleagues reported that IL-10 achieved a maximum value four hours after skin incision with levels returning to baseline by POD1 [203]. In 11 infants undergoing cardiopulmonary bypass operations, IL-10 levels also peaked $24 \mathrm{~h}$ after termination of bypass $(351.0+/-304.0 \mathrm{pg} / \mathrm{mL})$ [204]. In patients with cancer this increase in IL-10 could be detremental for patients undergoing surgery by contributing to postoperative NK cell suppression.

In the context of cancer, pegylated IL-10 has been shown to mediate tumor regression via tumor-infiltrating $\mathrm{CD}^{+} \mathrm{T}$ cell expansion and enhacement of immune checkpoint inihibitors [205]. Conversely, a meta-analysis of serum IL-10 in 1788 cancer patients showed that high seurm IL-10 levels were significantly associated with worse OS and disease-free survival (DFS) at 1 year, 3 years, and 5 years for both solid and hematological malignancies [206]. In addition, in vitro rIL-10 has been shown to act as a tumor growth factor to enhance human melanoma cell proliferation [205]. Thus, IL-10 may not be an ideal target given its pleiotropic effects on NK cells and in the context of cancer. A potential therapeutic may include the use of an anti-IL-10 monoclonal antibody, such as BT063 [207], to block the suppressive effects on postoperative NK cells, although there is currently a paucity of studies describing the clinical use of such a therapeutic (Table 1).

\section{Transforming Growth Factor $\beta 1$}

TGF $\beta 1$ is essential to wound healing. During granulation tissue formation, TGF $\beta 1$ induces the expression of fibronectin, collagen I and III, and VEGF in addition to improving the angiogenic properties of endothelial progenitor cells, promoting keratinocyte migration, and stimulating contraction of fibroblasts [208]. TGF $\beta 1$ may therefore be important in postoperative wound healing in response to surgical trauma, however there is a paucity of research investigating TGF $\beta 1$ in the postoperative period. Our group profiled $26 \mathrm{cy}-$ tokines and chemokines using a multianalyte protein array in B16LacZ tumor-bearing surgically stressed and untreated mice [24]. At $18 \mathrm{~h}$ post-operation, surgically stressed mice showed a significant increase in plasma TGF $\beta 1$, IL-5, and IL-6 [24]. While there exists a knowledge-gap when it comes to the postoperative period, TGF $\beta 1$ is well known to have pro-tumorigenic and anti-inflammatory properties. In fact, TGF $\beta 1$ is pathologically upregulated in humans as a result of tumor cell proliferation, can be secreted by tumor cells, and is a negative predictor of DFS and OS [116,209-211]. Moreover, there is a direct relationship between TGF $\beta 1$ levels and metastatic burden in a variety of cancers $[210,212,213]$. Thus, TGF $\beta 1$ may therefore be a provocative target to reverse postoperative immune suppression and prevent cancer recurrence.

In terms of its immunosuppressive properties, TGF $\beta 1$ has been shown to promote the development of $\mathrm{T}_{\text {regs }}$ and suppressive myeloid-derived suppressor cells (MDSCs), prevent the activation and differentiation of $\mathrm{CD} 4^{+}$and $\mathrm{CD} 8^{+} \mathrm{T}$ cells, inhibit the maturation and antigen presenting capacity of DCs via downregulation of MHC II, and dampen NK cell proliferation, cytotoxicity, and IFN $\gamma$ secretion $[56,77,213,214]$. In culture, TGF $\beta 1$ can override IL-2 activation of NK cells and induce the downregulation of NKp30, NKp46, DNAM-1, and NKG2D [214,215]. In addition to the downregulation of NK cell receptors, TGF $\beta 1$ is reported to suppress IFN $\gamma$ production through Smad-dependent repression of "master regulator" transcription factor T-bet [216]. Moreover, Viel et al., showed that TGF $\beta 1$ signaling opposed the IL-15-induced phosphorylation of both S6 and 4EBP1 (mTORC1 substrates) and Akt (mTORC2 substrate). The effect of TGF $\beta 1$ was comparable to the mTORC1 inhibitor rapamycin [56], suggesting a critical role for mTOR inhibition in mediating the effects of TGF $\beta 1$ on NK cells. Furthermore, suppression of TGF $\beta 1$ signaling in NK cells reduced metastases in two murine models of cancer (B16-F10 melanoma and RM-1 prostate adenocarcinoma) [56]. TGF $\beta 1$ was also able to reduce NK cell production of 
perforin, granzyme $\mathrm{B}, \mathrm{IFN} \gamma$, and macrophage inflammatory protein (MIP)- $1 \beta$ in response to stimulation by K562s in the presence of IL-2. In vivo, NK cell development was arrested by TGF $\beta 1$ signaling or mTOR depletion while mTOR activity and NK cell cytotoxicity were enhanced by TGF $\beta$ RII depletion [56].

Potential therapies targeting postoperative TGF $\beta 1$ can be divided into three categories: (1) preventing ligand-receptor interactions using ligand traps (soluble receptors and mAbs, i.e., fresolimumab) [217,218], (2) anti-receptor mAbs (i.e., LY3022859 [219]), and (3) preventing TGF $\beta 1$ signal transduction (i.e., BBI608 [220] or Celecoxib [221]) (Table 1). Viel et al., showed that the addition of an anti-TGF $\beta$ mAb enhanced IL-15-induced mTOR activity in murine splenocytes [56]. Mariathasan and colleagues showed that co-administration of anti-TGF $\beta$ and anti-PD-L1 mAbs in an EMT6 murine model of mammary carcinoma facilitated T cell-mediated anti-tumor immunity and tumor regression [222]. Nam et al., assessed the efficacy of an anti-TGF $\beta \mathrm{mAb}$ in a transplantable $4 \mathrm{~T} 1$ model of metastatic breast cancer and reported increased infiltration of T and NK cells, increased expression of NKG2D and cytotoxic granules, and enhanced $\mathrm{CD}^{+} \mathrm{T}$ cell-mediated anti-tumor responses [223]. Alvarez and colleagues also investigated the effects of an anti-TGF $\beta$ mAb in combination with rIL-2 and found significant increases in the numbers and functionality of NK cells and CD8 ${ }^{+} \mathrm{T}$ cells. In addition, this combination therapy significantly increased survival of mice injected with 3LL Lewis lung carcinoma cells in a CD8 ${ }^{+} \mathrm{T}$ cell- and NK celldependent manner. Despite these promising results in preclinical cancer models, targeting TGF $\beta 1$ in the postoperative period may have adverse effects related to wound healing, as TGF $\beta 1$ is known to play a role. However, this role is complex as TGF $\beta 1$ can both stimulate and protract wound re-epithelialization. One study investigated the temporal effects of TGF $\beta$ in a rabbit dermal ulcer model and reported the administration of an anti-TGF $\beta$ $\mathrm{mAb}$ early after injury resulted in delayed wound healing, while administration of the $\mathrm{mAb}$ at 7 days post-injury did not affect wound healing but reduced hypertrophic scar formation [224]. This is likely due to TGF $\beta$-mediated fibrosis [224,225]. Thus, there is more to be learned about the role of TGF $\beta$ in postoperative immune suppression to inform whether the above therapeutic strategies would prove to be beneficial in reducing metastasis and cancer recurrence.

\section{The Expansion of Immunosuppressive Cell Populations: Willing Accomplices?}

Two major postoperative suppressive cell populations are T regulatory cells $\left(\mathrm{T}_{\text {regs }}\right)$ and myeloid-derived suppressor cells (MDSCs) [176,183].

\subsection{Regulatory T Cells}

Regulatory $\mathrm{T}$ cells are a highly immunosuppressive subset of $\mathrm{T}$ cells that play an important role in maintaining immune homeostasis. $\mathrm{T}_{\text {regs }}$ were originally indentified by Sakaguchi et al., as $\mathrm{CD} 4^{+} \mathrm{CD} 25^{+} \mathrm{T}$ cells with crucial roles in maintaining self-tolerance and thus preventing autoimmunity [226-228]. $\mathrm{T}_{\text {regs }}$ are a heterogeneous population that can be divided into: $\mathrm{CD}_{4} \mathrm{RA}^{+}$FoxP3 ${ }^{\text {low }}$ resting $\mathrm{T}_{\text {regs }}, \mathrm{CD} 4 \mathrm{RA} \mathrm{F}^{-}$FoxP $3^{\text {high }}$ activated $\mathrm{T}_{\text {regs }}$, and CD45RA-FoxP3 ${ }^{\text {low }}$ cytokine-secreting $\mathrm{T}_{\text {regs }}$ [229]. Activated $\mathrm{T}_{\text {regs }}$ can inhibit the maturation of antigen-presenting cells such as DCs in an antigen-specific manner. Moreover, they can impact immune cell function by consumption of IL-2 via the high affinity IL-2 receptor, secretion of inhibitory cytokines including IL-10, TGF $\beta$, and IL-35 and degradation of ATP [230]. Finally, $\mathrm{T}_{\text {reg }}$ function and proliferation are promoted by catecholamines and prostaglandins [231-234]. As a result of their role in immune regulation, $\mathrm{T}_{\text {regs }}$ have been implicated in many diseases, including cancer.

In the context of cancer, $\mathrm{T}_{\text {regs }}$ have been reported to infiltrate the TME in both murine and human tumors accounting for up to $50 \%$ of $\mathrm{CD}^{+} \mathrm{T}$ cells. Furthermore, increased infiltration of $\mathrm{T}_{\text {regs }}$ is associated with poor prognosis [235-239]. Within the TME, $\mathrm{T}_{\text {regs }}$ can suppress various types of effector lymphocytes inculding $\mathrm{CD}^{+} \mathrm{T}_{\mathrm{h}}$ cells, CD8 ${ }^{+} \mathrm{CTLs}$, and

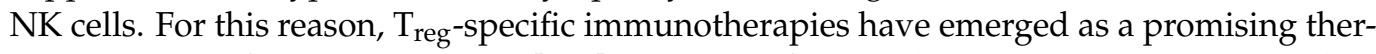
apeutic option for cancer patients [183]. In terms of surgical stress, $\mathrm{T}_{\text {regs }}$ were reported to 
decrease immediately following surgery, due to their association with the TME [228]. However, Saito et al., collected blood from cancer patients pre- and postoperatively until POD6 and found that regulatory $\mathrm{T}$ cell subsets increased to higher levels than those observed preoperatively and that this increase was proportional to surgical stress and invasiveness of the surgery, revealing $\mathrm{T}_{\text {regs }}$ to be a novel marker of surgical stress [240]. This was also observed in patients who received a radical mastectomy where the peripheral $\mathrm{T}_{\text {reg }}$ population was significantly expanded postoperatively [232]. Interestingly, postoperative stress was reported to induce $T_{\text {regs }}$ expression of FoxP3, TGF $\beta 1$, PD-1 and PD-L1, suggesting that postoperative $T_{\text {regs }}$ may have greater suppressive capacity than their preoperative counterparts [241]. Thus, the expansion of $\mathrm{T}_{\text {regs }}$ in the postoperative period may play a critical role in the maintenance of an anti-inflammatory state, resulting in cellular immune suppression and cancer recurrence.

A growing body of literature has revealed the important suppressive activity of $\mathrm{T}_{\text {regs }}$ on NK cell functions [242]. As reviewed by Orentas et al., a detectable expansion in the $\mathrm{T}_{\text {reg }}$ cell subset in many types of cancers was inversely correlated to the frequency and function of NK cells [243]. $\mathrm{T}_{\text {regs }}$ have been shown to suppress NK cell function via numerous mechanisms, most notably cytokine and soluble factor release [227,244], membrane-bound TGF $\beta$ expression [227,245], and competitive IL-2 consumption [244]. Ghiringhelli et al., demonstrated that in vitro co-culture of NK cells with $\mathrm{T}_{\text {regs }}$ led to reduced IL-12-mediated IFN $\gamma$ secretion and $\mathrm{K} 562$ lysis as compared to co-culture with conventional $\mathrm{CD} 4^{+} \mathrm{CD} 25^{+}$ $\mathrm{T}$ cells. In a murine model, NK: $\mathrm{T}_{\text {reg }}$ co-culture similarly resulted in suppression of Yac1 cell lysis [246]. However, TGF $\beta^{-/-} \mathrm{T}_{\text {regs }}$ were unable to suppress NK cell function, suggesting the importance of TGF $\beta$ in $\mathrm{T}_{\text {reg-mediated immunosuppression [246]. In vivo murine }}$ injection of $\mathrm{T}_{\text {regs }}$ significantly increased B16 metastatic burden compared to control, conventional T cells [246]. Morever, the authors demonstrated that membrane-bound TGF $\beta$ mediated contact-dependent mechanisms of suppression leading to reduced NKG2D. This, alongside other studies, demonstrated that blocking this interaction can prevent NK cell inhibition [246]. In addition to the expression of membrane-bound TGF $\beta, \mathrm{T}_{\text {regs }}$ have also been reported to secrete TGF $\beta$ as well as IL-10, IL-35, granzyme A/B, and perforin [227]. Finally, $T_{\text {regs }}$ express IL-2R while producing very little IL-2, thus resulting in increased IL-2 consumption. IL-2 is critical for both the expansion and maintenance of $\mathrm{T}_{\text {regs }}$ as well as their suppressive functions [247]. Furthermore, the consumption of IL-2 has been shown to limit IL-2-mediated activiation of NK cells and subsequent IFN $\gamma$ and granzyme B production and TRAIL expression in mice [227].

Depletion of $\mathrm{T}_{\text {regs }}$ by genetic knockout or pharmological inihbition has led to improved NK cell activty and tumor clearance in both human and murine studies [246]. This suggests that targeting $\mathrm{T}_{\text {regs }}$ could be a viable therapuetic strategy in the perioperative period. Several clinically available therapeutics have demonstrated efficacy in selectively targeting $\mathrm{T}_{\text {regs }}$ and improving NK cell function. Ghiringhelli et al., demonstrated that low oral doses of cyclophosphamide in advanced chemotherapy-resistant cancers provided a selective reduction of $T_{\text {regs }}$ while restoring NK cell activity [248] (Table 1). In addition, PD-1 and CTLA-4 checkpoint blockade was shown to reduce $\mathrm{T}_{\text {reg }}$ activity and improve immune effector function [249,250]. Furthermore, lenalidomide (Revlimid; CC-5013) and pomalidomide (CC-4047) are immunomodulatory drugs that are approved for the treatment of MM and have been shown to inhibit the proliferation and function of $\mathrm{T}_{\text {regs }}$ [251] (Table 1). Davies et al., reported an expansion of CD3 ${ }^{-} \mathrm{CD}^{2} 6^{+} \mathrm{NK}$ cells with significantly higher cytotoxicity against MM cell lines in MM patients who had received lenalidomide or pomalidomide, as compared to controls. Finally, depletion of $\mathrm{CD} 56^{+}$cells blocked the drug-induced MM cell lysis, further suggesting that the anti-tumor effects of these drugs are mediated via NK cells [252]. Potential side effects of these therapeutics include anemia, impaired wound healing, thrombocytopenia, and deep vein thrombosis.

The suppressive effects of $T_{\text {regs }}$ have also been blocked by the presence of IL-2, IL-4, IL-7, and IL-12 in vivo in cancer patients [253]. This suggests that cytokine administration prior to surgery could provide a protective effect against $\mathrm{T}_{\text {reg }}$-mediated immunosuppres- 
sion. Moreover, NK cell activity is inversely proportional to $\mathrm{T}_{\text {reg }}$ counts as observed by Chin et al., implicating that the activation of either cell type inhibits the other [254]. Brillard et al., reported that autologous IL-2-activated NK cells in humans and mice blocked $\mathrm{T}_{\text {reg }}$ proliferation via the secretion of high levels of IFN $\gamma$, skewing the environment towards $\mathrm{T}_{\mathrm{h}} 1$ polarization [255]. Furthermore, Roy et al., using Mycobacterium tuberculosis as a model, demonstrated that NK cells inhibited the conversion of $\mathrm{FOXP}^{+}$cells into $\mathrm{T}_{\text {regs }}$ and induced direct apoptosis of existing $\mathrm{T}_{\text {regs }}$ during the response to infection in healthy individuals [256]. Thus, given $\mathrm{T}_{\text {regs }}$ ability to potently suppress NK cell function and the context of their postoperative expansion, therapeutics to deplete postoperative $\mathrm{T}_{\text {regs }}$ or boost $\mathrm{NK}$ cell function to overcome $\mathrm{T}_{\text {reg }}$-mediated suppression should be further investigated for perioperative use.

\subsection{Myeloid-Derived Suppressor Cells}

Evolutionarily, myeloid cells are important host protectors, acting to prevent infection and aid in tissue remodelling [257]. However, chronic inflammation, infection, and cancer result in persistent myelopoiesis that generates myeloid cells with aberrant genomic profiles and suppressive activity $[257,258]$. These suppressive cells are termed myeloid-derived suppressor cells and are characterized as a heterogenous population of immature myeloid lineage immunoregulatory cells. MDSCs are hypothesized to develop via a two-signal model. The first signal serves to inhibit terminal differentiation of myeloid progenitors and the second signal induces their pathological activation [257]. This signal is produced in response to chronic inflammation and includes stimulation with GM-CSF, G-CSF, M-CSF, VEGF, and polyunsaturated fatty acids. The second signal is mediated by pro-inflammatory cytokines and DAMPs and includes stimulation with IFN $\gamma$, IL-1 $\beta$, IL-4, IL-6, IL-13, TNF, and HMGB1 [259]. MDSCs are made up of granulocytic or polymorphonuclear- MDSCs (PMN-MDSCs) and monocytic-MDSCs (M-MDSCs), with M-MDSCs being more suppressive on a per cell basis. PMN-MDSCs are phenotypically and morphologically similar to neutrophils, while M-MDSCs are similar to monocytes. Perhaps due to their relatively recent coming of age in the immunology world, there is still some controversy around how to define these cells, what their specific functions are, and the mechanisms by which they accomplish them. Phenotypically, these cells are lineage marker negative (CD3 ${ }^{-}, \mathrm{CD}^{-} 6^{-}$, and $\left.\mathrm{CD} 19^{-}\right)$. Human PMN-MDSCs are generally identified as CD11b ${ }^{+} \mathrm{CD}_{14}^{-} \mathrm{CD} 15^{+} \mathrm{CD} 33^{+}$

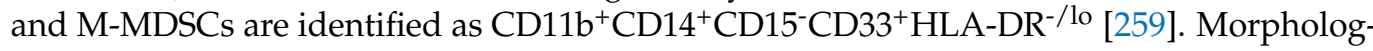
ically, MDSCs display weak phagocytic activity, increased reactive oxygen species (ROS) formation, high expression of ARG1, inducible nitric oxide synthase (iNOS), COX-2, and anti-inflammatory cytokines TGF $\beta$ and IL-10 [257,259,260]. Regardless of their nomenclature, MDSCs are ultimately defined by their ability to suppress immune cell function.

Cancer results in chronic inflammation and many of the "first signals" in the twosignal model of MDSC development are produced by tumor cells [258]. As such, MDSCs play a critical role in mediating tumorigenesis and immune evasion. MDSCs can directly promote tumor progression by affecting TME remodelling and angiogenesis via soluble factors like VEGF and can inhibit tumor cell senescence by antagonizing IL-1 $\alpha$ [257,260]. Moreover, MDSCs induce immune cell tolerance through immune cell supression through the various mechanisms described above. Clinically, peripheral MDSCs are an independent indicator of poor prognosis and poor outcome in solid and hematological malignancies and can help predict response to cancer therapies [259,261]. Veglia et al., recently summarized pre-clinical and clinical studies investigating the role of MDSCs in cancer [259]. A positive correlation between circulating MDSCs and cancer stage/tumor burden has been reported in colorectal carcinomas, NSCLC, breast, bladder, and thyroid cancers [261-268]. Zhang et al., performed a systematic review assessing the relationship between MDSCs and the prognosis of patients with solid tumors and reported elevated circulating MDSCs were an independent indicator of poor patient outcomes [269]. This is corroborated by studies that have shown shorter progression free interval/OS in patients with NSCLS, CRC, bladder, thyroid, uterine, or cervical cancer [261,266-268,270-272]. In hematological 
malignancies, M-MDSC numbers correlated with reduced survival in patients with MM and lymphoma (Hodgkin's, non-Hodgkin's, diffuse late B cell) [273-275]. In fact, in 2016, MDSCs were shown to predict resistance to checkpoint inhibitors (CPIs) [276]. Thus, the presence of MDSCs is detrimental for cancer patients and provides a complex target for cancer immunotherapies.

Acute physiologic insult results in the recruitment of granulocytes and the release of endogenous danger signals and inflammatory mediators into the circulation. In response, hematopoietic stem and progenitor cells in the bone marrow undergo a process termed "emergency myelopoiesis", which results in the production of myeloid cells, including MDSCs. It is well established that inflammatory mediators such as IL-1, IL-6, and prostaglandins stimulate this accumulation of MDSCs $[277,278]$. Sander et al., showed that MDSC accumulation was dependent upon gp130 (IL-6) signaling, as gp130-deficient mice did not accumulate MDSCs following sepsis [279]. As discussed, IL-6 and prostaglandins are highly upregulated in response to surgical stress, implicating a role for surgery as a driver of emergency myelopoiesis $[280,281]$. Although this process is critical for potentiating early innate immune responses, it also contributes to the expansion of highly immunosuppressive cells, which provide an immunological window for tumor cell survival following surgery. MDSCs have recently been shown to expand rapidly in response to surgical stress in both murine models [282-284] and in humans [84,285,286]. In a 4T1 breast cancer model, Ma et al., showed a postoperative increase in MDSCs that preferentially infiltrated the TME and promoted metastasis. MDSCs promoted EMT of tumor cells through TGF $\beta$, VEGF, and IL-10. In addition, anti-Gr1 antibody treatment reduced postoperative pulmonary metastases [283]. Similarly, $\mathrm{Xu}$ et al., showed that surgery results in an increase in MDSCs and a concomitant increase in colorectal cancer CT26 tumor cell growth via chemokine (C-X-C motif) ligand 4 (CXCL4) downregulation. Inoculation using a CXCL4 over-expressing CT26 tumor abrogated MDSC infiltration and reduced MDSC migration in vitro [284]. In addition, Wang et al., demonstrated a significant increase in M-MDSCs in lung cancer patients after thoracotomy as compared to preoperative levels. Furthermore, M-MDSC expansion positively corelated with $\mathrm{T}_{\text {reg }}$ expansion [285].

As previously stated, MDSCs are ultimately defined by their ability to suppress both innate and adaptive immune cell function. In terms of Natural Killer cells, MDSCs are able to suppress NK cell functions through both contact-dependent and -independent mechanisms, as previously reviewed by Market et al. [183]. Contact-dependent mechanisms include the engagement of germline receptors, such as TIGIT [287] and NKp30 [288], as well as via the expression of membrane-bound TGF $\beta 1$ [289]. Contact-independent mechanisms include the upregulation of ARG1 and/or iNOS and/or and the generation of nitric oxide (NO) [290].

While some mechanisms of MDSC-mediated immune suppression and tumor progression have been elucidated, the mechanism(s) by which surgery-induced MDSCs (sxMDSCs) mediate postoperative cancer recurrence are currently incomplete. sxM-MDSCs were reported to interact in a contact-dependent manner with $\mathrm{CD}^{+} \mathrm{T}$ cells to induce the expansion of FoxP3 ${ }^{+} \mathrm{T}_{\text {regs. }}$. Additionally, differentiation of MDSCs in the context of a murine model was shown to reduced postoperative sxM-MDSCs and $\mathrm{T}_{\text {regs }}$ and resulted in fewer lung nodules [285]. Taken together, this strongly implicates sxMDSCs and $\mathrm{T}_{\text {regs }}$ in the development of postoperative metastasis.

Due to their association with cancer severity and survival and their immunosuppressive capacity, MDSCs have become an important immunotherapeutic target. Specifically, MDSC modulation is associated with significant therapeutic benefit in preclinical models and early phase trials (reviewed in 2018 by Fleming et al.) and has been achieved by: (1) inhibiting MDSC immunosuppressive activity, (2) blocking MDSC migration to the TME, and (3) depletion of MDSCs [260]. The activity of iNOS, ARG1, and COX-2 can be inhibited using phosphodiesterase type 5 (PDE5) inhibitors (sildenafil and tadalafil) $[260,282]$ and the class I histone deacetylase inhibitor entinostat alone or in combination with anti-PD-1 antibodies [260] (Table 1). Our group studied the effects of the PDE5 inhibitor sildenafil in 
a murine model of surgical stress and found that sildenafil was able to abrogate the suppressive effects of sxMDSCs on NK cells and reduce lung metastases postoperatively [282]. We and others have shown that PDE5 inhibitors can decrease MDSC ARG1 and iNOS expression, and we hypothesize that this is the mechanism responsible for the observed effects in vivo [291]. We are currently testing the effects of the PDE5 inhibitor tadalafil in conjunction with an influenza vaccine on MDSC function in a Phase $1 \mathrm{~b}$ clinical trial (PERIOP-04) [292]. ARG1 activity can also be inhibited by nor-NOHA, which has been shown to improve NK cell ADCC in 4T1 bearing mice [293]. The transcription factor STAT3 is involved in immunosuppressive pathways and can be blocked using siRNA or decoy oligonucleotides in combination with immune checkpoint inhibitors or $\mathrm{CpG}$ oligonucleotides (TLR9 agonists). In addition, pharmacological inhibition of fatty acid oxidation has been shown to decrease the immunosuppressive capacity of MDSCs. MDSC migration can be impaired by blocking chemokine signaling using small molecule inhibitors or chemotherapeutic drugs, such as Reparixin [260,294] or MK7123 [260,295]. The MDSC population can be depleted by inhibiting the conversion of immature myeloid cells into MDSCs using dimethyl amiloride or omeprazole to reduce extracellular vesicles in serum. Furthermore, MDSCs can be induced to differentiate into mature DCs or macrophages using the vitamin A derivative all-trans retinoid acid (aTRA) or chemotherapeutic agents like docetaxel. In a murine model, perioperative atRA, known to induce the differentiation of immature cells, reduced postoperative sxM-MDSCs and $\mathrm{T}_{\text {regs }}$ and resulted in fewer lung nodules [285]. Finally, tyrosine kinase inhibitors like sunitinib have been reported to reduce circulating MDSCs, chemotherapeutics like gemcitabine and 5-fluorouracil can induce selective apoptosis of MDSCs, and mAbs such as anti-Gr1 mAb have been used to deplete MDSCs in murine models [260,289]. However, while widely used, the efficacy of anti-Gr1 depletion on both MDSC subtypes is controversial, as M-MDSCs express less Gr1 [296,297]. Although many of these therapeutics have been tested only in the context of cancer, they could also be applied to target sxMDSCs and could be tested for safety and efficacy using our murine model of surgical stress. It is important to note, however, that sxMDSCs may also play a role in homeostasis in response to postoperative inflammation, as they have recently been reported to be beneficial in the context of pregnancy, obesity, diabetes, and autoimmune disorders [298].

\section{Acquitted: Surgery-Independent Mechanisms Anesthesia, Analgesia, and Blood Transfusions}

Surgical stress results in profound and complex postoperative changes. These changes directly and indirectly, through cellular immune suppression, affect cancer cell growth, proliferation, and migration leading to increased metastasis and cancer recurrence. However, other perioperative interventions may also have an impact on postoperative metastasis. Anesthesia, analgesia, and blood transfusions are all known to modulate the inflammatory response and have recently been shown to impact cancer progression [110].

\section{Double Agents? Anesthesia and Analgesia Having Varying Effects on Postoperative Metastasis}

Propofol is the most commonly used intravenous anesthetic for induction and maintenance of anesthesia, while volatile agents, such as sevoflurane and isoflurane, are also commonly used for maintenance of anesthesia during surgery. Propofol has been shown to have anti-cancer properties as well as the potential to boost NK cell function. Zhou and colleagues investigated the effects of propofol on NK cell phenotype and function in patients with esophageal squamous cell carcinoma and found that propofol enhanced NK cell cytotoxicity through the expression of germline receptors [232]. Additional studies of co-culture models with the the colon cancer cell line SW620 [299] and the gastric cancer cell line BGC-823 [300] have also shown that propofol promotes NK cell cytotoxicity in vitro. Thus, propofol's anti-cancer effects may be mediated by enhanced NK cell killing, although other hypothesized mechanisms include inhibition of oncogenes and the downregulation of HIF- $1 \alpha$ and subsequent inhibition of angiogenesis [301]. 
As compared to propofol, the literature on the effects of volatile anesthetics on NK cell function is mixed. Lim et al., assessed the effects of propofol versus sevoflurane on NK cells isolated from patients who underwent breast cancer surgery. They found no difference in NK cell numbers or in cancer cell apoptosis and NK cell-derived cytokines when cultured in vitro with a breast cancer cell line [302]. However, Tazawa and colleagues assessed NK92-MI cytotoxicity, proliferation, conjugation, lytic granule polarization, and degranulation in a co-culture system with K562 cells and found that isoflurane and sevoflurane attenuated cytotoxicity, conjugation, and polarization of NK cells via LFA-1 inhibition [303]. Additionally, in a prospective randomized clinical study of patients undergoing breast cancer surgery, isolated NK cell cytotoxicity increased compared to baseline in patients who had received propofol-ketorolac compared to a decrease in cytotoxicity seen in patients that had received sevoflurane-fentanyl [304]. There even appears to be differences between volatile anesthetics in terms of their effects on NK cell function. Markovic et al., assessed interferon stimulation of NK cells in mice anesthetized with isoflurane versus halothane and found that while both anesthetics inhibited NK cell cytotoxicity, halothane induced more profound suppression [305]. In addition to their immunosuppressive effects, volatile agents have also been shown to stimulate proliferation and migration of cancer cells in vitro [110], in addition to inducing HIF-1 $\alpha$ expression [306], therefore promoting cancer recurrence. Thus, there is much left to be uncovered about the effects of anesthetics on NK cell function and the role of anesthetics in cancer recurrence. As a result, numerous clinical trials are currently underway to address these unanswered questions [149,307].

Two commonly used classes of analgesics include opioids and NSAIDs. Opioids are potent analgesics that can also be used as anesthetic adjuncts perioperatively. In contrast to NSAIDs, the majority of preclinical studies suggest that opioids have procancer effects $[110,117]$ and retrospective reviews have associated opioid administration with increased cancer recurrence [110]. Opioids have been shown to suppress NK cell cytotoxicity via multiple mechanisms, including stimulation of the HPA axis, thereby inhibiting NK cell function through the release of immunosuppressive GCs, and the inhibition of NK cell migration via mu receptor activation [196]. Moreover, Shavit et al., used a rat lung tumor model to show that fentanyl $(0.1-0.3 \mathrm{mg} / \mathrm{kg})$ induced a dosedependent increase in lung tumor retention and lung metastases [308]. Finally, a study by Desmond et al., reported reduced NK cell infiltration into breast cancer tissue in women who received more systemic perioperative opioids [309].

There is growing evidence to support the anti-cancer effects of COX-inhibiting NSAIDs, which act by reducing prostaglandin production. Preclinical studies have reported reduced cancer cell viability, proliferation, and migration through COX-dependent and -independent mechanisms while animal models suggest potential mechanisms may include reduced VEGF and the downregulation of oncogenes [310,311]. In a retrospective clinical study, combined NSAID (Flubiprofen Axetil)-dexamethasone resulted in enhanced survival of NSCLC patients [44] and is currently being investigated in a Phase 4 clinical trial (NCT03172988). However, these anti-cancer mechanisms are likely independent of innate immunity, as NSAIDs have been shown to suppress innate NK cell cytokine secretion $(\mathrm{IFN} \gamma, \mathrm{TNF} \alpha)$ in a COX-independent manner [170].

Thus, different anesthetics and analgesics have varying pro- and anti-cancer effects. Due to this variation and a lack of standardization for anesthetic/analgesic use in the perioperative period, the administration of anesthetics/analgesics perioperatively is unlikely to be the unifying mechanism responsible for metastatic recurrence across all cancer surgery patients.

\section{Copycat Crime: Blood Transfusions Suppress Postoperative NK Cell Activity}

The transfusion of RBCs and other blood products may be required during surgery. Blood transfusions have consistently been associated with immunosuppression and inflammation in vitro [312-315]. In the context of "pure" RBC transfusions, transfusion-related immunomodulation (TRIM) is thought to be mediated by monocytes/macrophages [313]. 
Specific to NK cells, in 1992, Jensen et al., assessed NK cell function preoperatively and postoperatively on POD3, 7, and 30 in elective CRC surgery patients. They found that, compared to patients that did not receive a transfusion or received filtered blood free from leukocytes, patients transfused with whole blood had significantly impaired NK cell cytotoxicity via ${ }^{51} \mathrm{Cr}$-release assay up to POD3 [314]. Similarily, Ghio and colleagues found that NK cells isolated from patients who received whole blood transfusion had reduced cytotoxic activity on day 3, which improved by day 7 after transfusion [315]. Clinically, blood transfusions have been associated with increased cancer recurrence, postoperative infection, and increased morbidity in a variety of cancer types, including gastric, esophageal, prostate, and bladder [316-320]. A 2006 Cochrane meta-analysis of CRC patients reported an overall odds ratio for recurrence of 1.42 in patients that received a blood transfusion ( $95 \%$ CI: 1.2 1.67) [321]. Interestingly, transfusion of autologous salvaged blood resulted in increased $\mathrm{NK}$ cell precursors and IFN $\gamma$ production as compared to allogeneic transfusion [322]. However, the literature supports a consistent suppression of the cellular immune response in both transfused and non-transfused cancer surgery patients. This strongly suggests that although blood transfusions may contribute to postoperative immunosuppression and metastasis, it is not the primary mechanism.

\section{The Verdict: Guilty}

Surgery results in a paradoxical increase in metastasis and cancer recurrence and there exist numerous potential mechanisms that may contribute to this phenomenon. This process is likely multifactorial and may involve all of the potential mechanisms discussed here, however, evidence supports a primary role for postoperative immune suppression, specifically a suppression of NK cells. The inability of surgically stressed NK cells to carry out effector functions is devastating for the anti-tumor immune response.

Although currently there are no FDA-approved perioperative therapeutics, numerous pre-clinical and clinical investigations are aimed at identifying and testing such therapeutics. Novel therapies may target the many hypothesized mechanisms of postoperative metastasis, which indirectly result in immune suppression, or they may target suppressive cytokines and immune cell populations, or they may involve perioperative boosting of NK cell function. Specifically, studies targeting soluble factors and suppressive cell populations during the anti-inflammatory phase of the postoperative period have shown promising results. It will be critical to apply the previously discussed immunotherapeutics in an NK cell-specific manner, as the disturbance of perioperative processes may also impact wound healing and patient recovery. The perioperative period of immunosuppression presents a window of opportunity for such therapeutics to prevent metastases and cancer recurrence for thousands of cancer patients who undergo tumor resection each year.

Author Contributions: M.M. and G.T. contributed to writing and editing the manuscript. R.C.A. contributed to editing the manuscript. All authors have read and agreed to the published version of the manuscript.

Funding: The authors received funding from the following agencies: Cancer Research Society (CRS), Canadian Institutes of Health Research (CIHR), and the Ontario Student Assistance Program through an Ontario Graduate Scholarship and a Queen Elizabeth II Graduate Scholarship in Science and Technology.

Conflicts of Interest: The authors have no conflict of interest to declare.

\section{References}

1. The Cancer Atlas. The American Cancer Society. 2014. Available online: https://canceratlas.cancer.org/the-burden/northernamerica/ (accessed on 3 April 2021).

2. Canadian Cancer Society's Advisory Committee on Cancer Statistics. Canadian Cancer Statistics; Canadian Cancer Society: Toronto, ON, Canada, 2017.

3. Lakhtakia, R.A. Brief history of breast cancer: Part I: Surgical domination reinvented. Sultan Qaboos Univ. Med. J. 2014, 14, e166.

4. Hajdu, S.I. A note from history: Landmarks in history of cancer, part 1. Cancer 2011, 118, 1097-1102. [CrossRef] 
5. American Cancer Society: The History of Cancer. Available online: https://www.cancer.org/cancer/cancer-basics/history-ofcancer.html (accessed on 23 May 2021).

6. Hajdu, S.I. Greco-Roman Thought about Cancer. Cancer 2004, 100, 2048-2051. [CrossRef]

7. Robinson, D.H.; Toledo, A.H. Historical development of modern anesthesia. J. Investig. Surgery. 2012, 25, 141-149. [CrossRef]

8. Arruebo, M.; Vilaboa, N.; Sáez-Gutierrez, B.; Lambea, J.; Tres, A.; Valladares, M.; González-Fernández, Á. Assessment of the evolution of cancer treatment therapies. Cancers 2011, 3, 3279-3330. [CrossRef] [PubMed]

9. Freeman, M.D.; Gopman, J.M.; Salzberg, C.A. The evolution of mastectomy surgical technique: From mutilation to medicine. Gland. Surg. 2018, 7, 308-315. [CrossRef] [PubMed]

10. Mukherjee, S.; Ghoshal, S. The Emperor of All Maladies: A Biography of Cancer. J. Postgrad. Med. Educ. Res. 2012, 46, 112. [CrossRef]

11. Sudhakar, A. History of Cancer, Ancient and Modern Treatment Methods. J. Cancer Sci. Ther. 2009, 1, 1-4. [CrossRef]

12. Fisher, B.; Jeong, J.; Anderson, S.; Bryant, J.; Fisher, E.R.; Wolmark, N. Twenty-Five-Year Follow-up of a Randomized Trial Comparing Radical Mastectomy, Total Mastectomy, and Total Mastectomy Followed by Irradiation. N. Engl. J. Med. 2002, 347, 567-575. [CrossRef]

13. Wagner, M.; Redaelli, C.; Lietz, M.; Seiler, C.A.; Friess, H.; Büchler, M.W. Curative resection is the single most important factor determining outcome in patients with pancreatic adenocarcinoma. BJS 2004, 91, 586-594. [CrossRef] [PubMed]

14. Perini, M.; Montagnini, A.; Jukemura, J.; Penteado, S.; Abdo, E.; Patzina, R.; Cecconello, I.; Cunha, J. Clinical and pathologic prognostic factors for curative resection for pancreatic cancer. HPB 2008, 10, 356-362. [CrossRef] [PubMed]

15. Brown, K.M. Pancreaticoduodenectomy Is Curative in the Majority of Patients with Node-Negative Ampullary Cancer. Arch. Surg. 2005, 140, 529-532. [CrossRef]

16. Cancer Quest: Cancer Treatments. Available online: https://www.cancerquest.org/patients/treatments (accessed on 21 March 2021).

17. The History of Cancer. Available online: https://www.cancer.org/cancer/cancer-basics/history-of-cancer/cancer-treatmentsurgery.html (accessed on 2 February 2021).

18. Demicheli, R.; Retsky, M.W.; Hrushesky, W.J.M.; Baum, M.; Gukas, I.D. The effects of surgery on tumor growth: A century of investigations. Ann. Oncol. 2008, 19, 1821-1828. [CrossRef]

19. Marie, P.; Clunet, J. Fréquences des métastases viscérales chez les souris canceéreuses après ablation chirurgicale de leur tumeur. Bull. Assoc. Fr. Etud. Cancer 1910, 3, 19-23.

20. Tyzzer, E.E. Factors in the Production and Growth of tumor Metastases. J. Med. Res. 1913, 28, 309-332. [PubMed]

21. Ehrlich, P.; Apolant, H. Beobechtungen über maligne Mäusetumoren. Berl. Klein. Wchnshr. 1905, 42, 871-874.

22. Hadfield, G. The dormant cancer cell. Br. Med. J. 1954, 2, 607-610. [CrossRef]

23. Sugarbaker, E.; Ketcham, A.; Cohen, A. Studies of dormant tumour cells. Cancer 1971, 28, 545-552. [CrossRef]

24. Tai, L.H.; De Souza, C.T.; Bélanger, S.; Ly, L.; Alkayyal, A.A.; Zhang, J.; Rintoul, J.L.; Ananth, A.A.; Lam, T.; Breitbach, C.J. Preventing postoperative metastatic disease by inhibiting surgery-induced dysfunction in natural killer cells. Cancer Res. 2013, 73, 97-107. [CrossRef] [PubMed]

25. Angka, L.; Martel, A.B.; Kilgour, M.; Jeong, A.; Sadiq, M.; De Souza, C.T.; Baker, L.; Kennedy, M.A.; Kekre, N.; Auer, R.C. Natural Killer Cell IFN $\gamma$ Secretion is Profoundly Suppressed Following Colorectal Cancer Surgery. Ann. Surg. Oncol. 2018, 25, 3747-3754. [CrossRef]

26. Kiessling, R.; Klein, E.; Wigzell, H. “Natural” killer cells in the mouse. Eur. J. Immunol. 1975, 5, 112-117. [CrossRef]

27. Pollock, R.E.; Lotzová, E.; Stanford, S.D. Mechanism of surgical stress impairment of human perioperative natural killer cell cytotoxicity. Arch. Surg. 1991, 126, 338-342. [CrossRef]

28. Baginska, J.; Viry, E.; Paggetti, J.; Medves, S.; Berchem, G.; Moussay, E.; Janji, B. The critical role of the tumor microenvironment in shaping natural killer cell-mediated anti-tumor immunity. Front. Immunol. 2013, 4, 490. [CrossRef]

29. Cooper, M.; Fehniger, T.; Turner, S.C.; Chen, K.; Ghaheri, B.A.; Ghayur, T.; Carson, I.W.E.; Caligiuri, M.A. Human natural killer cells: A unique innate immunoregulatory role for the CD56bright subset. Blood 2001, 97, 3146-3151. [CrossRef]

30. Vivier, E.; Tomasello, E.; Baratin, M.; Walzer, T.; Ugolini, S. Functions of natural killer cells. Nat. Immunol. 2008, 9, 503-510. [CrossRef]

31. Paust, S.; Senman, B.; Von Andrian, U.H. Adaptive immune responses mediated by natural killer cells. Immunol. Rev. 2010, 235, 286-296. [CrossRef]

32. Chester, C.; Fritsch, K.; Kohrt, H.E. Natural killer cell immunomodulation: Targeting activating, inhibitory, and co-stimulatory receptor signaling for cancer immunotherapy. Front. Immunol. 2015, 6, 601. [CrossRef]

33. Waldhauer, I.; Steinle, A. NK cells and cancer immunosurveillance. Oncogene 2008, 27, 5932-5943. [CrossRef]

34. Mandal, A.; Viswanathan, C. Natural killer cells: In health and disease. Hematol. Oncol. Stem Cell Ther. 2015, 8, 47-55. [CrossRef]

35. Horton, N.C.; Mathew, P.A. NKp44 and Natural Cytotoxicity Receptors as Damage-Associated Molecular Pattern Recognition Receptors. Front. Immunol. 2015, 6, 31. [CrossRef]

36. Pende, D.; Castriconi, R.; Romagnani, P.; Spaggiari, G.M.; Marcenaro, S.; Dondero, A.; Lazzeri, E.; Lasagni, L.; Martini, S.; Rivera, P.; et al. Expression of the DNAM-1 ligands, Nectin-2 (CD112) and poliovirus receptor (CD155), on dendritic cells: Relevance for natural killer-dendritic cell interaction. Blood 2006, 107, 2030-2036. [CrossRef] 
37. Martinet, L.; de Andrade, L.F.; Guillerey, C.; Lee, J.S.; Liu, J.; Souza-Fonseca-Guimaraes, F.; Hutchinson, D.; Kolesnik, T.B.; Nicholson, S.E.; Huntington, N.D.; et al. DNAM-1 Expression Marks an Alternative Program of NK Cell Maturation. Cell Rep. 2015, 11, 85-97. [CrossRef]

38. Huntington, N.D.; Martinet, L.; Smyth, M.J. DNAM-1: Would the real natural killer cell please stand up! Oncotarget 2015, 6, 28537-28538. [CrossRef]

39. Lanier, L.L. NK Cell Recognition. Annu. Rev. Immunol. 2005, 23, 225-274. [CrossRef]

40. Marçais, A.; Cherfils-Vicini, J.; Viant, C.; Degouve, S.; Viel, S.; Fenis, A.; Rabilloud, J.; Mayol, K.; Tavares, A.; Bienvenu, J.; et al. The metabolic checkpoint kinase mTOR is essential for IL-15 signaling during the development and activation of NK cells. Nat. Immunol. 2014, 15, 749-757. [CrossRef]

41. Fung, M.M.; Rohwer, F.; McGuire, K.L. IL-2 activation of a PI3K-dependent STAT3 serine phosphorylation pathway in primary human T cells. Cell. Signal. 2003, 15, 625-636. [CrossRef]

42. Mocellin, S.; Panelli, M.C.; Wang, E.; Nagorsen, D.; Marincola, F.M. The dual role of IL-10. Trends Immunol. 2003, $24,36-43$. [CrossRef]

43. Mocellin, S.; Panelli, M.C.; Wang, E.; Rossi, C.R.; Pilati, P.; Nitti, D.; Lise, M.; Marincola, F.M. IL-10 stimulatory effects on human NK cells explored by gene profile analysis. Genes Immun. 2004, 5, 621-630. [CrossRef]

44. Huang, W.W.; Zhu, W.Z.; Mu, D.L.; Ji, X.Q.; Nie, X.L.; Li, X.Y.; Wang, D.X.; Ma, D. Perioperative management may improve long-term survival in patients after lung cancer surgery: A retrospective cohort study. Anesth. Anal. 2018, 126, 1666. [CrossRef]

45. Blanco, L.; Puente, J.; Carrasco, C.; Miranda, D.; Wolf, M.E.; Mosnaim, A.D. Effect of salmonella-infected human monocytes on natural killer cell cytotoxicity. In vitro studies. Int. Immunopharmacol. 2001, 1, 1285-1293. [CrossRef]

46. Moore, K.W.; Malefyt, R.D.W.; Robert, L.; Garra, A.O. Interleukin -10 and the Interleukin -10 Receptor. Mol. Cell. Biol. 2001, 19, 683-765.

47. Di Carlo, E.; Coletti, A.; Modesti, A.; Giovarelli, M.; Forni, G.; Musiani, P. Local release of interleukin-10 by transfected mouse adenocarcinoma cells exhibits pro- and anti-inflammatory activity and results in a delayed tumor rejection. Eur. Cytokine Netw. 1998, 9, 61-68.

48. Mantovani, A.; Sozzani, S.; Locati, M.; Allavena, P.; Sica, A. Macrophage polarization: Tumor-associated macrophages as a paradigm for polarized M2 mononuclear phagocytes. Trends Immunol. 2002, 23, 549-555. [CrossRef]

49. Conti, P.; Kempuraj, D.; Kandere, K.; Di Gioacchino, M.; Barbacane, R.C.; Castellani, M.L.; Felaco, M.; Boucher, W.; Letourneau, R.; Theoharides, T.C. IL-10, an inflammatory/inhibitory cytokine, but not always. Immunol. Lett. 2003, 86, 123-129. [CrossRef]

50. Fiorentino, D.; Zlotnik, A.; Vieira, P.; Mosmann, T.R.; Howard, M.; Moore, K.W.; O'Garra, A. IL-10 acts on the antigen-presenting cell to inhibit cytokine production by Th1 cells. J. Immunol. 1991, 146, 3444-3451.

51. Scheller, J.; Chalaris, A.; Schmidt-Arras, D.; Rose-John, S. The pro- and anti-inflammatory properties of the cytokine interleukin-6. Biochim. Biophys. Acta (BBA)—Bioenerg. 2011, 1813, 878-888. [CrossRef]

52. Cifaldi, L.; Prencipe, G.; Caiello, I.; Bracaglia, C.; Locatelli, F.; De Benedetti, F.; Strippoli, R. Inhibition of natural killer cell cytotoxicity by interleukin-6: Implications for the pathogenesis of macrophage activation syndrome. Arthritis Rheumatol. 2015, 67, 3037-3046. [CrossRef]

53. Vredevoe, D.L.; Widawski, M.; Fonarow, G.; Hamilton, M.; Martínez-Maza, O.; Gage, J.R. Interleukin-6 (IL-6) expression and natural killer (NK) cell dysfunction and anergy in heart failure. Am. J. Cardiol. 2004, 93, 1007-1011. [CrossRef]

54. Kang, Y.-J.; Jeung, I.C.; Park, A.; Park, Y.-J.; Jung, H.; Kim, T.-D.; Lee, H.G.; Choi, I.; Yoon, S.R. An increased level of IL-6 suppresses NK cell activity in peritoneal fluid of patients with endometriosis via regulation of SHP-2 expression. Hum. Reprod. 2014, 29, 2176-2189. [CrossRef]

55. Choy, E.; Rose-John, S. Interleukin-6 as a multifunctional regulator: Inflammation, immune response, and fibrosis. J. Scleroderma Relat. Disord. 2017, 2, S1-S5. [CrossRef]

56. Viel, S.; Marçais, A.; Guimaraes, F.S.-F.; Loftus, R.; Rabilloud, J.; Grau, M.; Degouve, S.; Djebali, S.; Sanlaville, A.; Charrier, E.; et al. TGF- $\beta$ inhibits the activation and functions of NK cells by repressing the mTOR pathway. Sci. Signal. 2016, 9, ra19. [CrossRef]

57. Wu, Y.; Tian, Z.; Wei, H. Developmental and functional control of natural killer cells by cytokines. Front. Immunol. 2017, 4, 930. [CrossRef]

58. Zamai, L.; Ahmad, M.; Bennett, I.; Azzoni, L.; Alnemri, E.S.; Perussia, B. Natural Killer (NK) Cell-mediated Cytotoxicity: Differential Use of TRAIL and Fas Ligand by Immature and Mature Primary Human NK Cells. J. Exp. Med. 1998, 188, $2375-2380$. [CrossRef]

59. Zaidi, M.R.; Merlino, G. The two faces of interferon- $\gamma$ in cancer. Clin. Cancer Res. 2011, 17, 6118-6124. [CrossRef]

60. Terunuma, H.; Deng, X.; Dewan, Z.; Fujimoto, S.; Yamamoto, N. Potential Role of NK Cells in the Induction of Immune Responses: Implications for NK Cell-Based Immunotherapy for Cancers and Viral Infections. Int. Rev. Immunol. 2008, 27, 93-110. [CrossRef]

61. Long, E.O.; Rajagopalan, S. Stress Signals Activate Natural Killer Cells. J. Exp. Med. 2002, 196, 1399-1402. [CrossRef]

62. Gao, J.; Zheng, Q.; Xin, N.; Wang, W.; Zhao, C. CD155, an onco-immunologic molecule in human tumors. Cancer Sci. 2017, 108, 1934-1938. [CrossRef]

63. Twomey, J.D.; Kim, S.-R.; Zhao, L.; Bozza, W.P.; Zhang, B. Spatial dynamics of TRAIL death receptors in cancer cells. Drug Resist. Updat. 2015, 19, 13-21. [CrossRef]

64. Takeda, K.; Stagg, J.; Yagita, H.; Okumura, K.; Smyth, M. Targeting death-inducing receptors in cancer therapy. Oncogene 2007, 26, 3745-3757. [CrossRef] [PubMed] 
65. Bubeník, J. Tumour MHC class I downregulation and immunotherapy (Review). Oncol. Rep. 2003, 10, 2005-2008. [CrossRef]

66. Bi, J.; Tian, Z. NK cell dysfunction and checkpoint immunotherapy. Front. Immunol. 2019, 10, 1999. [CrossRef]

67. Choi, S.I.; Lee, S.H.; Park, J.Y.; Kim, K.A.; Lee, E.J.; Lee, S.Y.; In, K.H. Clinical utility of a novel natural killer cell activity assay for diagnosing non-small cell lung cancer: A prospective pilot study. OncoTargets Ther. 2019, 12, 1661. [CrossRef]

68. Imai, K.; Matsuyama, S.; Miyake, S.; Suga, K.; Nakachi, K. Natural cytotoxic activity of peripheral-blood lymphocytes and cancer incidence: An 11-year follow-up study of a general population. Lancet 2000, 356, 1795-1799. [CrossRef]

69. Vidal, A.C.; Howard, L.E.; Wiggins, E.; De Hoedt, A.M.; Shiao, S.L.; Knott, S.; Taioli, E.; Fowke, J.H.; Freedland, S.J. Natural killer cell activity and prostate cancer risk in veteran men undergoing prostate biopsy. Cancer Epidemiol. 2019, 62, 101578. [CrossRef] [PubMed]

70. Jung, Y.S.; Kwon, M.-J.; Park, D.I.; Sohn, C.I.; Park, J.H. Association between natural killer cell activity and the risk of colorectal neoplasia. J. Gastroenterol. Hepatol. 2018, 33, 831-836. [CrossRef] [PubMed]

71. Lee, H.S.; Leem, G.; Kang, H.; Jo, J.H.; Chung, M.J.; Jang, S.J.; Yoon, D.H.; Park, J.Y.; Park, S.W.; Song, S.Y.; et al. Peripheral natural killer cell activity is associated with poor clinical outcomes in pancreatic ductal adenocarcinoma. J. Gastroenterol. Hepatol. 2020, 36, 516-522. [CrossRef]

72. Cho, H.; Ryu, M.-H.; Lee, H.E.; Kim, H.-D.; Kang, Y.-K. Prognostic value of natural killer cell activity for patients with HER2 + advanced gastric cancer treated with first line fluoropyrimidine-platinum doublet plus trastuzumab. Cancer Immunol. Immunother. 2021, 1-10. [CrossRef]

73. Choi, M.G.; Kim, Y.J.; Lee, J.C.; Rho, J.K.; Choi, C. Efficacy of natural killer cell activity as a biomarker for predicting immunotherapy response in non-small cell lung cancer. Thorac. Cancer 2020, 11, 3337-3345. [CrossRef]

74. Hansen, T.F.; Nederby, L.; Zedan, A.H.; Mejlholm, I.; Henriksen, J.R.; Steffensen, K.D.; Thomsen, C.B.; Raunkilde, L.; Jensen, L.H.; Jakobsen, A. Correlation Between Natural Killer Cell Activity and Treatment Effect in Patients with Disseminated Cancer. Transl. Oncol. 2019, 12, 968-972. [CrossRef]

75. Tang, Y.-P.; Xie, M.-Z.; Li, K.-Z.; Li, J.-L.; Cai, Z.-M.; Hu, B.-L. Prognostic value of peripheral blood natural killer cells in colorectal cancer. BMC Gastroenterol. 2020, 20, 1-9. [CrossRef]

76. Zhang, S.; Liu, W.; Hu, B.; Wang, P.; Lv, X.; Chen, S.; Shao, Z. Prognostic Significance of Tumor-Infiltrating Natural Killer Cells in Solid Tumors: A Systematic Review and Meta-Analysis. Front. Immunol. 2020, 11, 1242. [CrossRef]

77. Bisheshar, S.K.; De Ruiter, E.J.; Devriese, L.A.; Willems, S.M. The prognostic role of NK cells and their ligands in squamous cell carcinoma of the head and neck: A systematic review and meta-analysis. OncoImmunology 2020, 9, 1747345. [CrossRef]

78. Espinoza, J.L.; Nguyen, V.H.; Ichimura, H.; Pham, T.T.; Nguyen, C.H.; Pham, T.V.; Elbadry, M.I.; Yoshioka, K.; Tanaka, J.; Trung, L.Q.; et al. A functional polymorphism in the NKG2D gene modulates NK-cell cytotoxicity and is associated with susceptibility to Human Papilloma Virus-related cancers. Sci. Rep. 2016, 6, 39231. [CrossRef]

79. Jobin, G.; Rodriguez-Suarez, R.; Betito, K. Association between Natural Killer Cell Activity and Colorectal Cancer in High-Risk Subjects Undergoing Colonoscopy. Gastroenterology 2017, 153, 980-987. [CrossRef]

80. Koo, K.C.; Shim, D.H.; Yang, C.M.; Lee, S.-B.; Kim, S.M.; Shin, T.Y.; Kim, K.H.; Yoon, H.-G.Y.; Rha, K.H.; Lee, J.M.; et al. Reduction of the CD16-CD56bright NK Cell Subset Precedes NK Cell Dysfunction in Prostate Cancer. PLoS ONE 2013, 8, e78049. [CrossRef]

81. Lee, J.; Park, K.H.; Ryu, J.H.; Bae, H.J.; Choi, A.; Lee, H.; Lim, J.; Han, K.; Park, C.H.; Jung, E.S.; et al. Natural killer cell activity for IFN-gamma production as a supportive diagnostic marker for gastric cancer. Oncotarget 2017, 8, 70431-70440. [CrossRef]

82. Beldi-Ferchiou, A.; Caillat-Zucman, S. Control of NK cell activation by immune checkpoint molecules. Int. J. Mol. Sci. 2017, 18, 2129. [CrossRef]

83. Lazarova, M.; Steinle, A. Impairment of NKG2D-Mediated Tumor Immunity by TGF- $\beta$. Front. Immunol. 2019, 10, 2689. [CrossRef]

84. Paul, S.; Lal, G. The molecular mechanism of natural killer cells function and its importance in cancer immunotherapy. Front. Immunol. 2017, 8, 1124. [CrossRef]

85. Jun, E.; Song, A.Y.; Choi, J.-W.; Lee, H.H.; Kim, M.-Y.; Ko, D.-H.; Kang, H.J.; Kim, S.W.; Bryceson, Y.; Kim, S.C.; et al. Progressive Impairment of NK Cell Cytotoxic Degranulation Is Associated With TGF- $\beta 1$ Deregulation and Disease Progression in Pancreatic Cancer. Front. Immunol. 2019, 10, 1354. [CrossRef]

86. Lee, J.-C.; Lee, K.-M.; Kim, D.-W.; Heo, D.S. Elevated TGF- $\beta 1$ Secretion and Down-Modulation of NKG2D Underlies Impaired NK Cytotoxicity in Cancer Patients. J. Immunol. 2004, 172, 7335-7340. [CrossRef]

87. Brivio, F.; Gilardi, R.; Bucocev, R.; Ferrante, R.; Rescaldani, R.; Vigoré, L.; Fumagalli, L.; Nespoli, A.; Lissoni, P. Surgery-induced decline in circulating dendritic cells in operable cancer patients: A possible explanation of postoperative immunosuppression. Hepatogastroenterology 2000, 47, 1337-1339.

88. Ananth, A.A.; Tai, L.H.; Lansdell, C.; Alkayyal, A.A.; Baxter, K.E.; Angka, L.; Zhang, J.; Tanese de Souza, C.; Stephenson, K.B.; Parato, K.; et al. Surgical stress abrogates pre-existing protective T cell mediated anti-tumor immunity leading to postoperative cancer recurrence. PLoS ONE 2016, 11, e0155947.

89. Iannone, F.; Porzia, A.; Peruzzi, G.; Birarelli, P.; Milana, B.; Sacco, L.; Peparini, N.; Prezioso, G.; Battella, S. Effect of surgery on pancreatic tumor-dependent lymphocyte asset: Modulation of natural killer cell frequency and cytotoxic function. Pancreas 2015, 44, 386. [CrossRef]

90. Velásquez, J.F.; Ramírez, M.F.; Ai, D.I.; Lewis, V.; Cata, J.P. Impaired Immune Function in Patients Undergoing Surgery for Bone Cancer. Anticancer. Res. 2015, 35, 5461-5466. 
91. Reinhardt, R.; Pohlmann, S.; Kleinertz, H.; Hepner-Schefczyk, M.; Paul, A.; Flohé, S.B. Invasive Surgery Impairs the Regulatory Function of Human CD56 bright Natural Killer Cells in Response to Staphylococcus aureus. Suppression of Interferon- $\gamma$ Synthesis. PLoS ONE 2015, 10, e0130155. [CrossRef]

92. Alieva, M.; Van Rheenen, J.; Broekman, M.L.D. Potential impact of invasive surgical procedures on primary tumor growth and metastasis. Clin. Exp. Metastasis 2018, 35, 319-331. [CrossRef]

93. Ma, M.B.; Bartal, I.; Goldfarb, Y.; Levi, B.; Avraham, R.; Raz, A.; Ben-Eliyahu, S. Perioperative Use of $\beta$-blockers and COX-2 Inhibitors May Improve Immune Competence and Reduce the Risk of Tumor Metastasis. Ann. Surg. Oncol. 2008, 15, $2042-2052$. [CrossRef]

94. Goldfarb, Y.; Sorski, L.; Benish, M.; Levi, B.; Melamed, R.; Ben-Eliyahu, S. Improving postoperative immune status and resistance to cancer metastasis: A combined perioperative approach of immunostimulation and prevention of excessive surgical stress responses. Ann. Surg. 2011, 253, 798-810. [CrossRef]

95. Seth, R.; Tai, L.-H.; Falls, T.; de Souza, C.T.; Bell, J.C.; Carrier, M.; Atkins, H.; Boushey, R.; Auer, R.A. Surgical Stress Promotes the Development of Cancer Metastases by a Coagulation-Dependent Mechanism Involving Natural Killer Cells in a Murine Model. Ann. Surg. 2013, 258, 158-168. [CrossRef]

96. Tartter, P.I.; Steinberg, B.; Barron, D.M.; Martinelli, G. The Prognostic Significance of Natural Killer Cytotoxicity in Patients with Colorectal Cancer. Arch. Surg. 1987, 122, 1264-1268. [CrossRef]

97. Schantz, S.P.; Brown, B.W.; Lira, E.; Taylor, D.L.; Beddingfield, N. Evidence for the role of natural immunity in the control of metastatic spread of head and neck cancer. Cancer Immunol. Immunother. 1987, 25, 141-145. [CrossRef] [PubMed]

98. Fujisawa, T.; Yamaguchi, Y. Autologous tumor killing activity as a prognostic factor in primary resected nonsmall cell carcinoma of the lung. Cancer 1997, 79, 474-481. [CrossRef]

99. Maity, A.; Saha, D.; Swaika, S.; Maulik, S.G.; Choudhury, B.; Sutradhar, M. Detection of hypoxia in the early postoperative period. Anesthesia: Essays Res. 2012, 6, 34-37. [CrossRef]

100. Strachan, L.; Noble, D.W. Hypoxia and surgical patients-Prevention and treatment of an unnecessary cause of morbidity and mortality. J. R. Coll. Surg. Edinb. 2001, 46, 297-302.

101. Ehrenfeld, J.M.; Funk, L.M.; Van Schalkwyk, J.; Merry, A.; Sandberg, W.; Gawande, A. The incidence of hypoxemia during surgery: Evidence from two institutions. Can. J. Anaesth. 2010, 57, 888-897. [CrossRef]

102. Sun, Z.; Sessler, D.I.; Dalton, J.E.; Devereaux, P.; Shahinyan, A.; Naylor, A.J.; Hutcherson, M.; Finnegan, P.; Tandon, V.; DarvishKazem, S. Postoperative Hypoxemia Is Common and Persistent: A Prospective Blinded Observational Study. Anesth. Analg. 2015, 121, 709. [CrossRef]

103. Parodi, M.; Raggi, F.; Cangelosi, D.; Manzini, C.; Balsamo, M.; Blengio, F.; Eva, A.; Varesio, L.; Pietra, G.; Moretta, L.; et al. Hypoxia Modifies the Transcriptome of Human NK Cells, Modulates Their Immunoregulatory Profile, and Influences NK Cell Subset Migration. Front. Immunol. 2018, 9, 2358. [CrossRef]

104. Chambers, A.M.; Matosevic, S. Immunometabolic Dysfunction of Natural Killer Cells Mediated by the Hypoxia-CD73 Axis in Solid Tumors. Front. Mol. Biosci. Front. 2019, 6, 60. [CrossRef]

105. Balsamo, M.; Manzini, C.; Pietra, G.; Raggi, F.; Blengio, F.; Mingari, M.C.; Varesio, L.; Moretta, L.; Bosco, M.C.; Vitale, M. Hypoxia downregulates the expression of activating receptors involved in NK-cell-mediated target cell killing without affecting ADCC. Eur. J. Immunol. 2013, 43, 2756-2764. [CrossRef] [PubMed]

106. Teng, R.; Wang, Y.; Lv, N.; Zhang, D.; Williamson, R.A.; Lei, L.; Chen, P.; Lei, L.; Wang, B.; Fu, J.; et al. Hypoxia Impairs NK Cell Cytotoxicity through SHP-1-Mediated Attenuation of STAT3 and ERK Signaling Pathways. J. Immunol. Res. 2020, 2020, 4598476. [CrossRef] [PubMed]

107. Muz, B.; de la Puente, P.; Azab, F.; Azab, A.K. The role of hypoxia in cancer progression, angiogenesis, metastasis, and resistance to therapy. Hypoxia 2015, 3, 83. [CrossRef] [PubMed]

108. Chouaib, S.; Messai, Y.; Couve, S.; Escudier, B.; Hasmim, M.; Noman, M.Z. Hypoxia Promotes Tumor Growth in Linking Angiogenesis to Immune Escape. Front. Immunol. 2012, 3, 21. [CrossRef]

109. Kim, J.; Lim, S.A.; Moon, Y.; Shin, M.H.; Cassian, Y.; Park, H.; Lee, K. Normoxic to hypoxic switch of pre-activated NK cells leads to robust proliferation and enhanced effector function via stabilization of HIF-1 $\alpha$ and inhibition of apoptosis. J. Immunol. 2018, 13, 111.12.

110. Wall, T.; Sherwin, A.; Ma, D.; Buggy, D. Influence of perioperative anaesthetic and analgesic interventions on oncological outcomes: A narrative review. Br. J. Anaesth. 2019, 123, 135-150. [CrossRef]

111. Nobre, A.R.; Entenberg, D.; Wang, Y.; Condeelis, J.; Aguirre-Ghiso, J.A. The Different Routes to Metastasis via Hypoxia-Regulated Programs. Trends Cell Biol. 2018, 28, 941-956. [CrossRef]

112. Sarkar, S.; Germeraad, W.T.V.; Rouschop, K.M.A.; Steeghs, E.M.P.; Van Gelder, M.; Bos, G.M.J.; Wieten, L. Hypoxia Induced Impairment of NK Cell Cytotoxicity against Multiple Myeloma Can Be Overcome by IL-2 Activation of the NK Cells. PLoS ONE 2013, 8, e64835. [CrossRef]

113. Solocinski, K.; Padget, M.R.; Fabian, K.P.; Wolfson, B.; Cecchi, F.; Hembrough, T.; Benz, S.; Rabizadeh, S.; Soon-Shiong, P.; Schlom, J.; et al. Overcoming hypoxia-induced functional suppression of NK cells. J. Immunother. Cancer 2019, 8, e000246. [CrossRef]

114. Panelli, M.C.; White, R.; Foster, M.; Martin, B.; Wang, E.; Smith, K.; Marincola, F. Forecasting the cytokine storm following systematic interleukin (IL)-2 administration. J. Transl. Med. 2004, 2, 1-14. [CrossRef] 
115. Skrombolas, D.; Frelinger, J.G. Challenges and developing solutions for increasing the benefits of IL-2 treatment in tumor therapy. Expert Rev. Clin. Immunol. 2014, 10, 207-217. [CrossRef]

116. Shariat, S.F.; Shalev, M.; Menesses-Diaz, A.; Kim, I.Y.; Kattan, M.; Wheeler, T.M.; Slawin, K.M. Preoperative Plasma Levels of Transforming Growth Factor Beta1(TGF- $\beta 1$ ) Strongly Predict Progression in Patients Undergoing Radical Prostatectomy. J. Clin. Oncol. 2001, 19, 2856-2864. [CrossRef]

117. Desborough, J. The stress response to trauma and surgery. Br. J. Anaesth. 2000, 85, 109-117. [CrossRef]

118. Raytis, J.L.; Lew, M.W. Surgical Stress Response and Cancer Metastasis: The Potential Benefit of Perioperative Beta Blockade; Landes Bioscience: Austin, TX, USA, 2013.

119. Chung, J.F.; Lee, S.J.; Sood, A.K. Immunological and pleiotropic effects of individual $\beta$-blockers and their relevance in cancer therapies. Expert Opin. Investig. Drugs 2016, 25, 501-505. [CrossRef]

120. Chen, L.; Jondal, M.; Yakimchuk, K. Regulatory effects of dexamethasone on NK and T cell immunity. Inflammopharmacology 2017, 26, 1331-1338. [CrossRef]

121. Melamed, R.; Rosenne, E.; Shakhar, K.; Schwartz, Y.; Abudarham, N.; Ben-Eliyahu, S. Marginating pulmonary-NK activity and resistance to experimental tumor metastasis: Suppression by surgery and the prophylactic use of a $\beta$-adrenergic antagonist and a prostaglandin synthesis inhibitor. Brain Behav. Immun. 2005, 19, 114-126. [CrossRef]

122. Rosenne, E.; Shakhar, G.; Melamed, R.; Schwartz, Y.; Erdreich-Epstein, A.; Ben-Eliyahu, S. Inducing a mode of NK-resistance to suppression by stress and surgery: A potential approach based on low dose of poly I-C to reduce postoperative cancer metastasis. Brain Behav. Immun. 2007, 21, 395-408. [CrossRef]

123. Avraham, R.; Benish, M.; Inbar, S.; Bartal, I.; Rosenne, E.; Ben-Eliyahu, S. Synergism between immunostimulation and prevention of surgery-induced immune suppression: An approach to reduce post-operative tumor progression. Brain Behav. Immun. 2010, 24, 952-958. [CrossRef]

124. Capellino, S.; Claus, M.; Watzl, C. Regulation of natural killer cell activity by glucocorticoids, serotonin, dopamine, and epinephrine. In Cell Mol. Immunol.; 2020; 17, pp. 705-711. [CrossRef]

125. Vitale, C.; Chiossone, L.; Cantoni, C.; Morreale, G.; Cottalasso, F.; Moretti, S.; Pistorio, A.; Haupt, R.; Lanino, E.; Dini, G.; et al. The corticosteroid-induced inhibitory effect on NK cell function reflects down-regulation and/or dysfunction of triggering receptors involved in natural cytotoxicity. Eur. J. Immunol. 2004, 34, 3028-3038. [CrossRef] [PubMed]

126. Morgan, D.J.; Davis, D.M. Distinct Effects of Dexamethasone on Human Natural Killer Cell Responses Dependent on Cytokines. Front. Immunol. 2017, 8, 432. [CrossRef] [PubMed]

127. Eddy, J.L.; Krukowski, K.; Janusek, L.; Mathews, H.L. Glucocorticoids regulate natural killer cell function epigenetically. Cell. Immunol. 2014, 290, 120-130. [CrossRef]

128. Krukowski, K.; Eddy, J.; Kosik, K.L.; Konley, T.; Janusek, L.W.; Mathews, H.L. Glucocorticoid dysregulation of natural killer cell function through epigenetic modification. Brain Behav. Immun. 2011, 25, 239-249. [CrossRef]

129. Feelders, R.A. Medical therapy of hypercortisolism. In Encyclopedia of Endocrine Diseases; Elsevier: Amsterdam, The Netherlands, 2018; pp. 232-236.

130. Neeman, E.; Zmora, O.; Ben-Eliyahu, S. A New Approach to Reducing Postsurgical Cancer Recurrence: Perioperative Targeting of Catecholamines and Prostaglandins: Figure 1. Clin. Cancer Res. 2012, 18, 4895-4902. [CrossRef]

131. Shaashua, L.; Shabat-Simon, M.; Haldar, R.; Matzner, P.; Zmora, O.; Shabtai, M.; Sharon, E.; Allweis, T.; Barshack, I.; Hayman, L.; et al. Perioperative COX-2 and $\beta$-Adrenergic Blockade Improves Metastatic Biomarkers in Breast Cancer Patients in a Phase-II Randomized Trial. Clin. Cancer Res. 2017, 23, 4651-4661. [CrossRef]

132. Zmora, O.; Tulchinsky, H.; Wasserberg, N. Perioperative ß-Adrenergic Blocker and a COX2 Inhibitor in Patients Undergoing Resection for Primary Colon and Rectal Cancer: Effect on Tumor Recurrence and Postoperative Immune Perturbations. A Multicenter Randomized Prospective Trial. Available online: https://clinicaltrials.gov/ct2/show/record/NCT00888797 (accessed on 8 March 2021).

133. Chen, Y.; Wang, Y.; Zhuang, Y.; Zhou, F.; Huang, L. Mifepristone Increases the Cytotoxicity of Uterine Natural Killer Cells by Acting as a Glucocorticoid Antagonist via ERK Activation. PLoS ONE 2012, 7, e36413. [CrossRef]

134. Chen, X.-Y.; Zhuang, Y.-L.; Li, L.; Zhang, W.-W.; Huang, L.-L. The effect of mifepristone on the peripheral blood natural killer cell's cytotoxicity and expression of CD94/NKG2A and NKG2D during the implantation phase. Fertil. Steril. 2010, 93, 2615-2620. [CrossRef] [PubMed]

135. Rearte, B.; Maglioco, A.; Balboa, L.; Bruzzo, J.; Landoni, V.I.; Laborde, E.A.; Chiarella, P.; Ruggiero, R.A.; Fernández, G.C.; Isturiz, M.A. Mifepristone (RU486) restores humoral and T cell-mediated immune response in endotoxin immunosuppressed mice. Clin. Exp. Immunol. 2010, 162, 568-577. [CrossRef]

136. Check, J.H.; Sansoucie, L.; Chern, J.; Dix, E. Mifepristone Treatment Improves Length and Quality of Survival of Mice with Spontaneous Lung Cancer. Anticancer Res. 2010, 30, 119-122. [PubMed]

137. DeHart, R.M.; Morehead, M.S. Mifepristone. Ann. Pharmacother. 2001, 35, 707-719. [CrossRef]

138. Ferguson, I.; Scott, H. Systematic Review of the Effectiveness, Safety, and Acceptability of Mifepristone and Misoprostol for Medical Abortion in Low- and Middle-Income Countries. J. Obstet. Gynaecol. Can. 2020, 42, 1532-1542. [CrossRef]

139. Lison, S.; Weiss, G.; Spannagl, M.; Heindl, B. Postoperative changes in procoagulant factors after major surgery. Blood Coagul. Fibrinolysis 2011, 22, 190-196. [CrossRef] 
140. Lou, X.-L.; Sun, J.; Gong, S.-Q.; Yu, X.-F.; Gong, R.; Deng, H. Interaction between circulating cancer cells and platelets: Clinical implication. Chin. J. Cancer Res. 2015, 27, 450-460. [CrossRef]

141. Nieswandt, B.; Hafner, M.; Echtenacher, B.; Männel, D.N. Lysis of tumor cells by natural killer cells in mice is impeded by platelets. Cancer Res. 1999, 59, 1295-1300.

142. Kopp, H.-G.; Placke, T.; Salih, H.R. Platelet-Derived Transforming Growth Factor- $\beta$ Down-Regulates NKG2D Thereby Inhibiting Natural Killer Cell Antitumor Reactivity. Cancer Res. 2009, 69, 7775-7783. [CrossRef]

143. Placke, T.; Örgel, M.; Schaller, M.; Jung, G.; Rammensee, H.-G.; Kopp, H.-G.; Salih, H.R. Platelet-Derived MHC Class I Confers a Pseudonormal Phenotype to Cancer Cells That Subverts the Antitumor Reactivity of Natural Killer Immune Cells. Cancer Res. 2011, 72, 440-448. [CrossRef]

144. Wang, S.; Li, Z.; Xu, R. Human cancer and platelet interaction, a potential therapeutic target. Int. J. Mol. Sci. 2018, 19, 1246. (accessed on 21 April 2021). [CrossRef]

145. Hejna, M.; Raderer, M.; Zielinski, C.C. Inhibition of Metastases by Anticoagulants. J. Natl. Cancer Inst. 1999, 91, 22-36. [CrossRef]

146. Gasic, G.J.; Gasic, T.B.; Stewart, C.C. Antimetastatic effects associated with platelet reduction. Proc. Natl. Acad. Sci. USA 1968, 61, 46. [CrossRef]

147. Gasic, G.J.; Gasic, T.B.; Galanti, N.; Johnson, T.; Murphy, S. Platelet-Tumor-cell interactions in mice. The role of platelets in the spread of malignant disease. Int. J. Cancer 1973, 11, 704-718. [CrossRef]

148. Varki, N.M.; Varki, A. Heparin Inhibition of Selectin-Mediated Interactions during the Hematogenous Phase of Carcinoma Metastasis: Rationale for Clinical Studies in Humans. Semin. Thromb. Hemost. 2002, 28, 53-66. [CrossRef]

149. Palumbo, J.S.; Kombrinck, K.W.; Drew, A.F.; Grimes, T.S.; Kiser, J.H.; Degen, J.L.; Bugge, T. Fibrinogen is an important determinant of the metastatic potential of circulating tumor cells. Blood 2000, 96, 3302-3309. [CrossRef]

150. Palumbo, J.S.; Potter, J.M.; Kaplan, L.S.; Talmage, K.; Jackson, D.G.; Degen, J.L. Spontaneous hematogenous and lymphatic metastasis, but not primary tumor growth or angiogenesis, is diminished in fibrinogen-deficient mice. Cancer Res. 2002, 62, 6966-6972. [PubMed]

151. Kingston, R.D.; Fielding, J.W.L.; Palmer, M.K. Peri-operative heparin: A possible adjuvant to surgery in colo-rectal cancer? Int. J. Colorectal Dis. 1993, 8, 111-115. [CrossRef]

152. Von Tempelhoff, G.F.; Harenberg, J.; Niemann, F.; Hommel, G.; Kirkpatrick, C.J.; Heilmann, L. Effect of low molecular weight heparin (Certoparin) versus unfractionated heparin on cancer survival following breast and pelvic cancer surgery: A prospective randomized double-blind trial. Int. J. Oncol. 2000, 16, 815-839. [CrossRef]

153. Auer, R.A.C.; Scheer, A.S.; McSparron, J.I.; Schulman, A.R.; Tuorto, S.; Doucette, S.; Gonsalves, J.; Fong, Y. Postoperative Venous Thromboembolism Predicts Survival in Cancer Patients. Ann. Surg. 2012, 255, 963-970. [CrossRef]

154. Borsig, L.; Wong, R.; Feramisco, J.; Nadeau, D.R.; Varki, N.M.; Varki, A. Heparin and cancer revisited: Mechanistic connections involving platelets, P-selectin, carcinoma mucins, and tumor metastasis. Proc. Natl. Acad. Sci. USA 2001, 98, 3352-3357. [CrossRef]

155. Wei, M.; Tai, G.; Gao, Y.; Li, N.; Huang, B.; Zhou, Y.; Hao, S.; Zeng, X. Modified Heparin Inhibits P-selectin-mediated Cell Adhesion of Human Colon Carcinoma Cells to Immobilized Platelets under Dynamic Flow Conditions. J. Biol. Chem. 2004, 279, 29202-29210. [CrossRef]

156. Lazo-Langner, A.; Goss, G.D.; Spaans, J.N.; Rodger, M. The effect of low-molecular-weight heparin on cancer survival. A systematic review and meta-analysis of randomized trials. J. Thromb. Haemost. 2007, 5, 729-737. [CrossRef] [PubMed]

157. Auer, R.; Scheer, A.; Wells, P.S.; Boushey, R.; Asmis, T.; Jonker, D.; Carrier, M. The use of extended perioperative low molecular weight heparin (tinzaparin) to improve disease-free survival following surgical resection of colon cancer: A pilot randomized con-trolled trial. Blood Coagul. Fibrinolysis 2011, 22, 760-762. [CrossRef]

158. Auer, R.; Carrier, M. NCT01455831: A Multicentre Randomized Controlled Trial of the Use of Extended Peri-Operative Low Molecular Weight Heparin to Improve Cancer Specific Survival Following Surgical Resection of Colorectal Cancer. Available online: https: / / clinicaltrials.gov/ct2/show / NCT01455831 (accessed on 2 April 2021).

159. Pishko, A.M.; Lefler, D.S.; Gimotty, P.; Paydary, K.; Fardin, S.; Arepally, G.M.; Crowther, M.; Rice, L.; Vega, R.; Cines, D.B.; et al. The risk of major bleeding in patients with suspected heparin-induced thrombocytopenia. J. Thromb. Haemost. 2019, 17, 1956-1965. [CrossRef] [PubMed]

160. Zidane, M.; Schram, M.T.; Planken, E.W.; Molendijk, W.H.; Rosendaal, F.R.; van der Meer, F.J.M.; Huisman, M.V. Frequency of major hemorrhage in patients treated with unfractionated intravenous heparin for deep venous thrombosis or pulmonary embolism: A study in routine clinical practice. Arch. Intern. Med. 2000, 160, 2369-2373. [CrossRef] [PubMed]

161. Derhagopian, R.P.; Sugarbaker, E.V.; Ketcham, A. Inflammatory Oncotaxis. JAMA J. Am. Med. Assoc. 1978, 240, 374-375. [CrossRef]

162. Buvanendran, A.; Kroin, J.S.; Berger, R.A.; Hallab, N.J.; Saha, C.; Negrescu, C.; Moric, M.; Caicedo, M.S.; Tuman, K.J. Upregulation of Prostaglandin E2and Interleukins in the Central Nervous System and Peripheral Tissue during and after Surgery in Humans. Anesthesiology 2006, 104, 403-410. [CrossRef] [PubMed]

163. Yakar, I.; Melamed, R.; Shakhar, G.; Shakhar, K.; Rosenne, E.; Abudarham, N.; Page, G.G.; Ben-Eliyahu, S. Prostaglandin E2 Suppresses NK Activity In Vivo and Promotes Postoperative Tumor Metastasis in Rats. Ann. Surg. Oncol. 2003, 10, 469-479. [CrossRef] [PubMed]

164. Holt, D.; Ma, X.; Kundu, N.; Fulton, A. Prostaglandin E2 (PGE2) suppresses natural killer cell function primarily through the PGE2 receptor EP4. Cancer Immunol. Immunother. 2011, 60, 1577-1586. [CrossRef] [PubMed] 
165. Ma, X.; Holt, D.; Kundu, N.; Reader, J.; Goloubeva, O.; Take, Y.; Fulton, A.M. A prostaglandin E (PGE) receptor EP4 antagonist protects natural killer cells from PGE2-mediated immunosuppression and inhibits breast cancer metastasis. OncoImmunology 2013, 2, e22647. [CrossRef]

166. Joshi, P.C.; Zhou, X.; Cuchens, M.; Jones, Q. Prostaglandin E 2 Suppressed IL-15-Mediated Human NK Cell Function Through Down-Regulation of Common $\gamma$-Chain. J. Immunol. 2001, 166, 885-891. [CrossRef]

167. Roche-Nagle, G.; Connolly, E.M.; Eng, M.; Bouchier-Hayes, D.J.; Harmey, J.H. Antimetastatic activity of a cyclooxygenase-2 inhibitor. Br. J. Cancer 2004, 91, 359-365. [CrossRef]

168. Wei, D.; Wang, L.; He, Y.; Xiong, H.Q.; Abbruzzese, J.L.; Xie, K. Celecoxib Inhibits Vascular Endothelial Growth Factor Expression in and Reduces Angiogenesis and Metastasis of Human Pancreatic Cancer via Suppression of Sp1 Transcription Factor Activity. Cancer Res. 2004, 64, 2030-2038. [CrossRef]

169. Chen, S.-Z.; Cao, W.; Yue, P.; Hao, C.; Khuri, F.R.; Sun, S.-Y. Celecoxib Promotes c-FLIP Degradation through Akt-Independent Inhibition of GSK3. Cancer Res. 2011, 71, 6270-6281. [CrossRef]

170. Inaoka, M.; Kimishima, M.; Takahashi, R.; Shiohara, T. Non-steroidal anti-inflammatory drugs selectively inhibit cytokine pro-duction by NK cells and $\gamma \delta$ T cells. Exp. Dermatol. 2006, 15, 981-990. [CrossRef]

171. Bone, R.C.; Grodzin, C.J.; Balk, R.A. Sepsis: A New Hypothesis for Pathogenesis of the Disease Process. Chest 1997, 112, 235-243. [CrossRef]

172. Alazawi, W.; Pirmadjid, N.; Lahiri, R.; Bhattacharya, S. Inflammatory and Immune Responses to Surgery and Their Clinical Impact. Ann. Surg. 2016, 264, 73-80. [CrossRef]

173. Barnes, T.C.; Anderson, M.E.; Moots, R.J. The Many Faces of Interleukin-6: The Role of IL-6 in Inflammation, Vasculopathy, and Fibrosis in Systemic Sclerosis. Int. J. Rheumatol. 2011, 2011, 1-6. [CrossRef]

174. Luo, Y.; Zheng, S.G. Hall of fame among pro-inflammatory cytokines: Interleukin- 6 gene and its transcriptional regulation mechanisms. Front. Immunol. 2016, 7, 604. [CrossRef]

175. R\&D. TGF Beta Signaling Pathways. Available online: https://www.rndsystems.com/pathways/tgf-beta-signaling-pathways (accessed on 8 March 2021).

176. Angka, L.; Khan, S.T.; Kilgour, M.K.; Xu, R.; Kennedy, M.A.; Auer, R.C. Dysfunctional Natural Killer Cells in the Aftermath of Cancer Surgery. Int. J. Mol. Sci. 2017, 18, 1787. [CrossRef]

177. Narita, S.; Tsuchiya, N.; Kumazawa, T.; Maita, S.; Numakura, K.; Obara, T.; Tsuruta, H.; Saito, M.; Inoue, T.; Horikawa, Y.; et al. Comparison of Surgical Stress in Patients Undergoing Open Versus Laparoscopic Radical Prostatectomy by Measuring Perioperative Serum Cytokine Levels. J. Laparoendosc. Adv. Surg. Tech. 2013, 23, 33-37. [CrossRef]

178. Oka, Y.; Murata, A.; Nishijima, J.; Yasuda, T.; Hiraoka, N.; Ohmachi, Y.; Kitagawa, K.; Yasuda, T.; Toda, H.; Tanaka, N. Circulating interleukin 6 as a useful marker for pre-dicting postoperative complications. Cytokine 1992, 4, 298-304. [CrossRef]

179. Santonocito, C.; De Loecker, I.; Donadello, K.; Moussa, M.D.; Markowicz, S.; Gullo, A.; Vincent, J.-L. C-Reactive Protein Kinetics After Major Surgery. Anesthesia Analg. 2014, 119, 624-629. [CrossRef] [PubMed]

180. Rettig, T.C.D.; Verwijmeren, L.; Dijkstra, I.M.; Boerma, D.; van de Garde, E.M.W.; Noordzij, P.G. Postoperative Interleukin-6 Level and Early Detection of Complications After Elective Major Abdominal Surgery. Ann. Surg. 2016, 263, 1207-1212. [CrossRef] [PubMed]

181. Kaufmann, K.B.; Heinrich, S.; Staehle, H.F.; Bogatyreva, L.; Buerkle, H.; Goebel, U. Perioperative cytokine profile during lung surgery predicts patients at risk for postoperative complications-A prospective, clinical study. PLoS ONE 2018, 13, e0199807. [CrossRef] [PubMed]

182. Scher, J.U.; Pillinger, M.H. The Anti-Inflammatory Effects of Prostaglandins. J. Investig. Med. 2009, 57, 703-708. [CrossRef]

183. Market, M.; Baxter, K.E.; Angka, L.; Kennedy, M.A.; Auer, R.C. The Potential for Cancer Immunotherapy in Targeting SurgeryInduced Natural Killer Cell Dysfunction. Cancers 2018, 11, 2. [CrossRef]

184. Masjedi, A.; Hashemi, V.; Hojjat-Farsangi, M.; Ghalamfarsa, G.; Azizi, G.; Yousefi, M.; Jadidi-Niaragh, F. The significant role of interleukin-6 and its signaling pathway in the immunopathogenesis and treatment of breast cancer. Biomed. Pharmacother. 2018, 108, 1415-1424. [CrossRef]

185. Scheid, C.; Young, R.; McDermott, R.; Fitzsimmons, L.; Scarffe, J.H.; Stern, P.L. Immune function of patients receiving recombinant human interleukin-6 (IL-6) in a phase I clinical study: Induction of C-reactive protein and IgE and inhibition of natural killer and lymphokine-activated killer cell activity. Cancer Immunol. Immunother. 1994, 38, 119-126.

186. Nagasaki, T.; Hara, M.R.; Nakanishi, H.; Takahashi, H.; Sato, M.; Takeyama, H. Interleukin-6 released by colon cancer-associated fibroblasts is critical for tumour angiogenesis: Anti-interleukin-6 receptor antibody suppressed angiogenesis and inhibited tumour-stroma interaction. Br. J. Cancer 2013, 110, 469-478. [CrossRef] [PubMed]

187. Culig, Z.; Puhr, M. Interleukin-6 and prostate cancer: Current developments and unsolved questions. Mol. Cell. Endocrinol. 2018, 462, 25-30. [CrossRef]

188. Silva, E.M.; Mariano, V.S.; Pastrez, P.R.A.; Pinto, M.C.; Castro, G.; Syrjanen, K.J.; Longatto-Filho, A. High systemic IL-6 is associated with worse prognosis in patients with non-small cell lung cancer. PLoS ONE 2017, 12, e0181125. [CrossRef] [PubMed]

189. Gadó, K.; Domján, G.; Hegyesi, H.; Falus, A. Role of interleukin-6 in the pathogenesis of multiple myeloma. Cell Biol. Int. 2000, 24, 195-209. [CrossRef] 
190. Thomsen, M.; Kersten, C.; Sorbye, H.; Skovlund, E.; Glimelius, B.; Pfeiffer, P.; Johansen, J.S.; Kure, E.H.; Ikdahl, T.; Tveit, K.M.; et al. Interleukin-6 and C-reactive protein as prognostic biomarkers in metastatic colorectal cancer. Oncotarget 2016, 7, 75013-75022. [CrossRef] [PubMed]

191. Liu, Q.; Yu, S.; Li, A.; Xu, H.; Han, X.; Wu, K. Targeting interlukin-6 to relieve immunosuppression in tumor microenvironment. Tumor Biol. 2017, 39, 1010428317712445. [CrossRef]

192. Stover, D.G.; Del Alcazar, C.R.G.; Brock, J.; Guo, H.; Overmoyer, B.; Balko, J.; Xu, Q.; BArdia, A.; Tolaney, S.; Gelman, R. Phase II study of ruxolitinib, a selective JAK1/2 inhibitor, in patients with metastatic triple-negative breast cancer. NPJ Breast Cancer 2018, 4, 1-9. [CrossRef]

193. Karkera, J.; Steiner, H.; Li, W.; Skradski, V.; Moser, P.L.; Riethdorf, S.; Reddy, M.; Puchalski, T.; Safer, K.; Prabhakar, U.; et al. The anti-interleukin- 6 antibody siltuximab down-regulates genes implicated in tumorigenesis in prostate cancer patients from a phase I study. Prostate 2011, 71, 1455-1465. [CrossRef]

194. Chen, R.; Chen, B. Siltuximab (CNTO 328): A promising option for human malignancies. Drug Des. Devel. Ther. 2015,9 , 3455. [CrossRef] [PubMed]

195. Angevin, E.; Tabernero, J.; Elez, E.; Cohen, S.J.; Bahleda, R.; Van Laethem, J.L.; Ottensmeier, C.; Loipez-Martin, J.A.; Clive, S.; Joly, F.; et al. A Phase I/II, multiple-dose, dose-escalation study of siltuximab, an anti-interleukin-6 monoclonal antibody, in patients with advanced solid tumors. Clin. Cancer Res. 2014, 20, 2192-2204. [CrossRef] [PubMed]

196. Fizazi, K.; De Bono, J.; Flechon, A.; Heidenreich, A.; Voog, E.; Davis, N.; Qi, M.; Bandekar, R.; Vermeulen, J.; Cornfeld, M.; et al. Randomised phase II study of siltuximab (CNTO 328), an anti-IL-6 monoclonal antibody, in combination with mitoxantrone/prednisone versus mitoxantrone/prednisone alone in metastatic castration-resistant prostate cancer. Eur. J. Cancer 2012, 48, 85-93. [CrossRef] [PubMed]

197. Rossi, J.-F.; Négrier, S.; James, N.D.; Kocak, I.; Hawkins, R.; Davis, H.; Prabhakar, U.; Qin, X.; Mulders, P.; Berns, B. A phase I/II study of siltuximab (CNTO 328), an anti-interleukin-6 monoclonal antibody, in metastatic renal cell cancer. Br. J. Cancer 2010, 103, 1154-1162. [CrossRef]

198. Lin, Z.-Q.; Kondo, T.; Ishida, Y.; Takayasu, T.; Mukaida, N. Essential involvement of IL-6 in the skin wound-healing process as evidenced by delayed wound healing in IL-6-deficient mice. J. Leukoc. Biol. 2003, 73, 713-721. [CrossRef]

199. Kishimoto, T. The biology of interleukin-6. Blood 1989, 74, 1-10. [CrossRef]

200. Locci, M.; Lukas, C.; Combe, B.; Banal, F.; Cormier, G.; Couret, M.; Dougados, M.; Flipo, R.M.; Marcelli, C.; Pham, T.; et al. SAT0152 Safety of Surgery in Patients Treated with Tocili-zumab for Rheumatoid Arthritis: Data from The Regate Registry. Ann. Rheum. Dis. 2016, 75, 720. [CrossRef]

201. Oft, M. IL-10: Master Switch from Tumor-Promoting Inflammation to Antitumor Immunity. Cancer Immunol. Res. 2014, 2, 194-199. [CrossRef]

202. Klava, A.; Windsor, A.C.J.; Farmery, S.M.; Woodhouse, L.F.; Reynolds, J.V.; Ramsden, C.W.; Boylston, A.W.; Guillou, P.J. Interleukin-10: A role in the de-velopment of postoperative immunosuppression. Arch. Surg. 1997, 132, 425-429. [CrossRef]

203. Kato, M.; Honda, I.; Suzuki, H.; Murakami, M.; Matsukawa, S.; Hashimoto, Y. Interleukin-10 production during and after upper abdominal surgery. J. Clin. Anesth. 1998, 10, 184-188. [CrossRef]

204. Seghaye, M.C.; Duchateau, J.; Bruniaux, J.; Demontoux, S.; Bosson, C.; Serraf, A.; Lecronier, G.; Mokhfi, E.; Planche, C. Interleukin10 release related to cardiopul-monary bypass in infants undergoing cardiac operations. J. Thorac. Cardiovasc. Surg. 1996, 111, 545-553. [CrossRef]

205. Ni, G.; Zhang, L.; Yang, X.; Li, H.; Ma, B.; Walton, S.; Wu, X.; Yuan, J.; Wang, T.; Liu, X. Targeting interleukin-10 signalling for cancer immunotherapy, a promising and complicated task. Hum. Vaccines Immunother. 2020, 16, 2328-2332. [CrossRef]

206. Zhao, S.; Wu, D.; Wu, P.; Wang, Z.; Huang, J. Serum IL-10 Predicts Worse Outcome in Cancer Patients: A Meta-Analysis. PLoS ONE 2015, 10, e0139598. [CrossRef]

207. Wang, X.; Wong, K.; Ouyang, W.; Rutz, S. Targeting IL-10 Family Cytokines for the Treatment of Human Diseases. Cold Spring Harb. Perspect. Biol. 2017, 11, a028548. [CrossRef]

208. Pakyari, M.; Farrokhi, A.; Maharlooei, M.K.; Ghahary, A. Critical Role of Transforming Growth Factor Beta in Different Phases of Wound Healing. Adv. Wound Care 2013, 2, 215-224. [CrossRef]

209. Chen, X.-L.; Chen, Z.-Q.; Zhu, S.-L.; Liu, T.; Wen, Y.; Su, Y.S.; Xi, X.; Hu, Y.; Lian, L.; Liu, F. Prognostic value of transforming growth factor-beta in patients with colorectal cancer who undergo surgery: A meta-analysis. BMC Cancer 2017, 17, 240. [CrossRef]

210. Li, J.; Shen, C.; Wang, X.; Lai, Y.; Zhou, K.; Li, P.; Liu, L.; Che, G. Prognostic value of TGF- $\beta$ in lung cancer: Systematic review and meta-analysis. BMC Cancer 2019, 19, 691. [CrossRef]

211. Katz, L.H.; Li, Y.; Chen, J.S.; Muñoz, N.M.; Majumdar, A.; Chen, J.; Mishra, L. Targeting TGF- $\beta$ signaling in cancer. Expert Opin. Ther. Targets. 2013, 17, 743-760. [CrossRef]

212. Neel, J.-C.; Humbert, L.; Lebrun, J.-J. The Dual Role of TGF $\beta$ in Human Cancer: From Tumor Suppression to Cancer Metastasis. ISRN Mol. Biol. 2012, 2012, 381428. [CrossRef]

213. Padua, D.; Massagué, J. Roles of TGF $\beta$ in metastasis. Cell Res. 2009, 19, 89-102. [CrossRef]

214. Strobl, H.; Knapp, W. TGF- $\beta 1$ regulation of dendritic cells. Microb. Infect. 1999, 1, 1283-1290. [CrossRef]

215. Castriconi, R.; Cantoni, C.; Della Chiesa, M.; Vitale, M.; Marcenaro, E.; Conte, R.; Biassoni, R.; Bottino, C.; Moretta, L.; Moretta, A. Transforming growth factor $\beta 1$ inhibits ex-pression of NKP30 and NKG2d receptors: Consequences for the NK-mediated killing of dendritic cells. ISO4 Standard. Proc. Natl. Acad. Sci. USA 2003, 100, 4120-4125. [CrossRef] 
216. Yu, J.; Wei, M.; Becknell, B.; Trotta, R.; Liu, S.; Boyd, Z.; Jaung, M.S.; Blaser, B.; Sun, J.; Benson, D.M.; et al. Pro- and Antiinflammatory Cytokine Signaling: Reciprocal Antagonism Regulates Interferon-gamma Production by Human Natural Killer Cells. Immunity 2006, 24, 575-590. [CrossRef]

217. Vincenti, F.; Fervenza, F.C.; Campbell, K.N.; Diaz, M.; Gesualdo, L.; Nelson, P.; Praga, M.; Radhakrishnan, J.; Sellin, L.; Singh, A.; et al. A Phase 2, Double-Blind, Placebo-Controlled, Randomized Study of Fresolimumab in Patients with Steroid-Resistant Primary Focal Segmental Glomerulosclerosis. Kidney Int. Rep. 2017, 2, 800-810. [CrossRef]

218. Trachtman, H.; Fervenza, F.C.; Gipson, D.S.; Heering, P.; Jayne, D.; Peters, H.; Rota, S.; Remuzzi, G.; Rump, L.C.; Sellin, L.K.; et al. A phase 1 , single-dose study of fresolimumab, an anti-TGF- $\beta$ antibody, in treatment-resistant primary focal segmental glomerulosclerosis. Kidney Int. 2011, 79, 1236-1243. [CrossRef] [PubMed]

219. Tolcher, A.W.; Berlin, J.D.; Cosaert, J.; Kauh, J.; Chan, E.; Piha-Paul, S.A.; Amaya, A.; Tang, S.; Driscoll, K.; Kimbung, R.; et al. A phase 1 study of anti-TGF $\beta$ receptor type-II mono-clonal antibody LY3022859 in patients with advanced solid tumors. Cancer Chemother. Pharmacol. 2017, 79, 673-680. [CrossRef]

220. MacDonagh, L.; Gray, S.; Breen, E.; Cuffe, S.; Finn, S.P.; O’Byrne, K.J.; Barr, M.P. BBI608 inhibits cancer stemness and reverses cisplatin resistance in NSCLC. Cancer Lett. 2018, 428, 117-126. [CrossRef] [PubMed]

221. Gong, L.; Thorn, C.F.; Bertagnolli, M.M.; Grosser, T.; Altman, R.B.; Klein, T.E. Celecoxib pathways: Pharmacokinetics and pharmacodynamics. Pharmacogenet. Genom. 2012, 2, 310-318.

222. Mariathasan, S.; Turley, S.J.; Nickles, D.; Castiglioni, A.; Yuen, K.; Wang, Y.; Iii, E.E.K.; Koeppen, H.; Astarita, J.L.; Cubas, R.; et al TGF $\beta$ attenuates tumour response to PD-L1 blockade by contributing to exclusion of T cells. Nature 2018, 554, 544-548. [CrossRef]

223. Nam, J.-S.; Terabe, M.; Mamura, M.; Kang, M.-J.; Chae, H.; Stuelten, C.; A Kohn, E.; Tang, B.; Sabzevari, H.; Anver, M.R.; et al. An Anti-Transforming Growth Factor $\beta$ Antibody Suppresses Metastasis via Cooperative Effects on Multiple Cell Compartments. Cancer Res. 2008, 68, 3835-3843. [CrossRef] [PubMed]

224. Lu, L.; Saulis, A.S.; Liu, W.R.; Roy, N.K.; Chao, J.D.; Ledbetter, S.; Mustoe, T.A. The temporal effects of anti-TGF- $\beta 1,2$, and 3 monoclonal an-tibody on wound healing and hypertrophic scar formation. J. Am. Coll. Surg. 2005, 201, 391-397. [CrossRef] [PubMed]

225. Yamakawa, S.; Hayashida, K. Advances in surgical applications of growth factors for wound healing. Burns Trauma 2019, 7, 10. [CrossRef] [PubMed]

226. Corthay, A. How do regulatory t cells work? Scand. J. Immunol. 2009, 70, 326-336. [CrossRef]

227. Schmidt, A.; Oberle, N.; Krammer, P.H. Molecular mechanisms oftreg-mediatedt cell suppression. Front. Immunol. 2012,3 , 51. [CrossRef]

228. Onizuka, S.; Tawara, I.; Shimizu, J.; Sakaguchi, S.; Fujita, T.; Nakayama, E. Tumor rejection by in vivo administration of anti-CD25 (interleukin-2 receptor alpha) monoclonal antibody. Cancer Res. 1999, 59, 3128-3133.

229. Miyara, M.; Yoshioka, Y.; Kitoh, A.; Shima, T.; Wing, K.; Niwa, A.; Parizot, C.; Taflin, C.; Heike, T.; Valeyre, D.; et al. Functional Delineation and Differentiation Dynamics of Human CD4+ T Cells Expressing the FoxP3 Transcription Factor. Immunity 2009, 30, 899-911. [CrossRef]

230. Tang, Q.; Adams, J.Y.; Tooley, A.J.; Bi, M.; Fife, B.; Serra, P.; Santamaria, P.; Locksley, R.M.; Krummel, M.F.; Bluestone, J.A. Visualizing regulatory T cell control of autoimmune responses in nonobese diabetic mice. Nat. Immunol. 2005, 7, 83-92. [CrossRef]

231. Kalinski, P. Regulation of Immune Responses by Prostaglandin E2. J. Immunol. 2011, 188, 21-28. [CrossRef]

232. Zhou, L.; Li, Y.; Li, X.; Chen, G.; Liang, H.; Wu, Y.; Tong, J.; Ouyang, W. Propranolol Attenuates Surgical Stress-Induced Elevation of the Regulatory T Cell Response in Patients Undergoing Radical Mastectomy. J. Immunol. 2016, 196, 3460-3469. [CrossRef]

233. Kohm, A.P.; Sanders, V.M. Norepinephrine and $\beta 2$-adrenergic receptor stimulation regulate CD4+ T and B lymphocyte function in vitro and in vivo. Pharmacol. Rev. 2001, 53, 487-525.

234. Madden, K.S. Catecholamines, sympathetic innervation, and immunity. Brain Behav. Immun. 2003, 17, S5-S10. [CrossRef]

235. Ohue, Y.; Nishikawa, H. Regulatory T (Treg) cells in cancer: Can Treg cells be a new therapeutic target? Cancer Sci. 2019, 110, 2080-2089. [CrossRef] [PubMed]

236. Najafi, M.; Farhood, B.; Mortezaee, K. Contribution of regulatory T cells to cancer: A review. J. Cell. Physiol. 2018, 234, 7983-7993. [CrossRef]

237. Ino, Y.; Yamazaki-Itoh, R.; Shimada, K.; Iwasaki, M.; Kosuge, T.; Kanai, Y.; Hiraoka, N. Immune cell infiltration as an indicator of the immune microenvironment of pancreatic cancer. Br. J. Cancer 2013, 108, 914-923. [CrossRef] [PubMed]

238. Zhang, S.; Pan, S.-B.; Lyu, Q.-H.; Wu, P.; Qin, G.-M.; Wang, Q.; He, Z.-L.; He, X.-M.; Wu, M.; Chen, G. Postoperative Regulatory T-Cells and Natural Killer Cells in Stage I Nonsmall Cell Lung Cancer Underwent Video-assisted Thoracoscopic Lobectomy or Thoracotomy. Chin. Med. J. 2015, 128, 1502-1509. [CrossRef]

239. Tang, Y.; Xu, X.; Guo, S.; Zhang, C.; Tang, Y.; Tian, Y.; Ni, B.; Wang, H. An increased abundance of tumor-infiltrating regulatory t cells is cor-related with the progression and prognosis of pancreatic ductal adenocarcinoma. PLoS ONE 2014, 9, e91551.

240. Saito, Y.; Shimada, M.; Utsunomiya, T.; Morine, Y.; Imura, S.; Ikemoto, T.; Mori, H.; Hanaoka, J.; Iwahashi, S.; Yamada, S.; et al. Regulatory T cells in the blood: A new marker of surgical stress. Surg. Today 2013, 43, 608-612. [CrossRef]

241. Dong, L.; Zheng, X.; Wang, K.; Wang, G.; Zou, H. Programmed death 1/programmed cell death-ligand 1 pathway participates in gastric surgery-induced imbalance of T-helper 17/regulatory T cells in mice. J. Trauma Acute Care Surg. 2018, 85, 549-559. [CrossRef] 
242. Pedroza-Pacheco, I.; Madrigal, A.; Saudemont, A. Interaction between natural killer cells and regulatory T cells: Perspectives for immunotherapy. Cell. Mol. Immunol. 2013, 10, 222-229. [CrossRef]

243. Orentas, R.J.; Kohler, M.E.; Johnson, B.D. Suppression of anti-cancer immunity by regulatory T cells: Back to the future. Semin. Cancer Biol. 2006, 16, 137-149. [CrossRef]

244. Littwitz-Salomon, E.; Akhmetzyanova, I.; Vallet, C.; Francois, S.; Dittmer, U.; Gibbert, K. Activated regulatory T cells suppress ef-fector NK cell responses by an IL-2-mediated mechanism during an acute retroviral infection. Retrovirology 2015, 12, 66. [CrossRef]

245. Pedroza-Pacheco, I.; Shah, D.; Domogala, A.; Luevano, M.; Blundell, M.; Jackson, N.; Thrasher, A.; Madrigal, A.; Saudemont, A. Regulatory T cells inhibit CD34+ cell differentiation into NK cells by blocking their proliferation. Sci. Rep. 2016, 6, 22097. [CrossRef] [PubMed]

246. Ghiringhelli, F.; Menard, C.; Terme, M.; Flament, C.; Taieb, J.; Chaput, N.; Puig, P.E.; Novault, S.; Escudier, B.; Vivier, E.; et al. $\mathrm{CD} 4+\mathrm{CD} 25+$ regulatory T cells inhibit natural killer cell functions in a transforming growth factor- $\beta$-dependent manner. J. Exp. Med. 2005, 202, 1075-1085. [CrossRef] [PubMed]

247. Chinen, T.; Kannan, A.K.; Levine, A.G.; Fan, X.; Klein, U.; Zheng, Y.; Gasteiger, G.; Feng, Y.; Fontenot, J.D.; Rudensky, A.Y. An essential role for the IL-2 receptor in T reg cell function. Nat. Immunol. 2016, 17, 1322-1333. [CrossRef]

248. Ghiringhelli, F.; Menard, C.; Puig, P.E.; Ladoire, S.; Roux, S.; Martin, F.; Solary, E.; Le Cesne, A.; Zitvogel, L.; Chauffert, B. Metronomic cyclophosphamide regimen selectively depletes CD4+CD25+ regulatory T cells and restores T and NK effector functions in end stage cancer patients. Cancer Immunol. Immunother. 2006, 56, 641-648. [CrossRef]

249. Peggs, K.S.; Quezada, S.; Chambers, C.A.; Korman, A.J.; Allison, J.P. Blockade of CTLA-4 on both effector and regulatory T cell compartments contributes to the antitumor activity of anti-CTLA-4 antibodies. J. Exp. Med. 2009, 206, 1717-1725. [CrossRef]

250. Curran, M.A.; Montalvo, W.; Yagita, H.; Allison, J.P. PD-1 and CTLA-4 combination blockade expands infiltrating T cells and re-duces regulatory T and myeloid cells within B16 melanoma tumors. Proc. Natl. Acad. Sci. USA 2010, 107, 4275-4280. [CrossRef]

251. Galustian, C.; Meyer, B.; Labarthe, M.C.; Dredge, K.; Klaschka, D.; Henry, J.; Todryk, S.; Chen, R.; Muller, G.; Stirling, D.; et al. The anti-cancer agents lenalidomide and poma-lidomide inhibit the proliferation and function of T regulatory cells. Cancer Immunol. Immunother. 2009, 58, 1033-1045. [CrossRef]

252. Davies, F.; Raje, N.; Hideshima, T.; Lentzsch, S.; Young, G.; Tai, Y.-T.; Lin, B.; Podar, K.; Gupta, D.; Chauhan, D.; et al. Thalidomide and immunomodulatory derivatives augment natural killer cell cytotoxicity in multiple myeloma. Blood 2001, 98, 210-216. [CrossRef]

253. Miller, J.S.; Soignier, Y.; Panoskaltsis-Mortari, A.; McNearney, S.A.; Yun, G.H.; Fautsch, S.K.; McKenna, D.; Le, C.; DeFor, T.E.; Burns, L.J.; et al. Successful adoptive transfer and in vivo expansion of human haploidentical NK cells in patients with cancer. Blood 2005, 105, 3051-3057. [CrossRef]

254. Chin, A.I.; Miyahira, A.; Covarrubias, A.; Teague, J.; Guo, B.; Dempsey, P.W.; Cheng, G. Toll-like Receptor 3-Mediated Suppression of TRAMP Prostate Cancer Shows the Critical Role of Type I Interferons in Tumor Immune Surveillance. Cancer Res. 2010, 70, 2595-2603. [CrossRef]

255. Brillard, E.; Pallandre, J.R.; Chalmers, D.; Ryffel, B.; Radlovic, A.; Seilles, E.; Rohrlich, P.S.; Pivot, X.; Tiberghien, P.; Saas, P.; et al. Natural killer cells prevent CD28-mediated Foxp3 transcription in CD4+CD25- T lymphocytes. Exp. Hematol. 2007, 35, 416-425. [CrossRef] [PubMed]

256. Roy, S.; Barnes, P.F.; Garg, A.; Wu, S.; Cosman, D.; Vankayalapati, R. NK Cells Lyse T Regulatory Cells That Expand in Response to an Intracellular Pathogen. J. Immunol. 2008, 180, 1729-1736. [CrossRef]

257. Gabrilovich, D.I. Myeloid-derived suppressor cells. Cancer Immunol. Res. 2017, 5, 3-8. [CrossRef] [PubMed]

258. Tesi, R. MDSC; The Most Important Cell You Have Never Heard Of. Trends Pharmacol. Sci. 2018, 40, 4-7. [CrossRef]

259. Veglia, F.; Perego, M.; Gabrilovich, D. Myeloid-derived suppressor cells coming of age review-article. Nat. Immunol. 2018, 19, 108-119. [CrossRef]

260. Fleming, V.; Hu, X.; Weber, R.; Nagibin, V.; Groth, C.; Altevogt, P.; Utikal, J.; Umansky, V. Targeting myeloid-derived suppressor cells to bypass tu-mor-induced immunosuppression. Front. Immunol. 2018, 9, 398. [CrossRef]

261. Yamauchi, Y.; Safi, S.; Blattner, C.; Rathinasamy, A.; Umansky, L.; Juenger, S.; Warth, A.; Eichhorn, M.; Muley, T.; Herth, F.J.F.; et al. Circulating and tumor myeloid-derived sup-pressor cells in resectable non-small cell lung cancer. Am. J. Respir. Crit Care Med. 2018, 198, 777-787. [CrossRef]

262. Sun, H.-L.; Zhou, X.; Xue, Y.-F.; Wang, K.; Shen, Y.-F.; Mao, J.-J.; Guo, H.-F.; Miao, Z.-N. Increased frequency and clinical significance of myeloid-derived suppressor cells in human colorectal carcinoma. World J. Gastroenterol. 2012, 18, $3303-3309$. [CrossRef] [PubMed]

263. Zhang, B.; Wang, Z.; Wu, L.; Zhang, M.; Li, W.; Ding, J.-H.; Zhu, J.; Wei, H.; Zhao, K. Circulating and Tumor-Infiltrating Myeloid-Derived Suppressor Cells in Patients with Colorectal Carcinoma. PLoS ONE 2013, 8, e57114. [CrossRef]

264. Arihara, F.; Mizukoshi, E.; Kitahara, M.; Takata, Y.; Arai, K.; Yamashita, T.; Nakamoto, Y.; Kaneko, S. Increase in CD14+HLADR - / low myeloid-derived suppressor cells in hepatocellular carcinoma patients and its impact on prognosis. Cancer Immunol. Immunother. 2013, 62, 1421-1430. [CrossRef] [PubMed]

265. Diaz-Montero, C.M.; Salem, M.; Nishimura, M.I.; Garrett-Mayer, E.; Cole, D.J.; Montero, A.J. Increased circulating myeloidderived suppressor cells correlate with clinical cancer stage, metastatic tumor burden, and doxorubicin-cyclophosphamide chemotherapy. Cancer Immunol. Immunother. 2008, 58, 49-59. [CrossRef] [PubMed] 
266. Yang, G.; Shen, W.; Zhang, Y.; Liu, M.; Zhang, L.; Liu, Q.; Lu, H.H.; Bo, J. Accumulation of myeloid-derived suppressor cells (MDSCs) induced by low levels of IL-6 correlates with poor prognosis in bladder cancer. Oncotarget 2017, 8, 38378-38388. [CrossRef] [PubMed]

267. Angell, T.E.; Lechner, M.; Smith, A.M.; Martin, S.E.; Groshen, S.G.; Maceri, D.R.; Singer, P.A.; Epstein, A.L. Circulating MyeloidDerived Suppressor Cells Predict Differentiated Thyroid Cancer Diagnosis and Extent. Thyroid 2016, 26, 381-389. [CrossRef]

268. Huang, A.; Zhang, B.; Wang, B.; Zhang, F.; Fan, K.-X.; Guo, Y.-J. Increased CD14+HLA-DR-/low myeloid-derived suppressor cells correlate with extrathoracic metastasis and poor response to chemotherapy in non-small cell lung cancer patients. Cancer Immunol. Immunother. 2013, 62, 1439-1451. [CrossRef]

269. Zhang, S.; Ma, X.; Zhu, C.; Liu, L.; Wang, G.; Yuan, X. The Role of Myeloid-Derived Suppressor Cells in Patients with Solid Tumors: A Meta-Analysis. PLoS ONE 2016, 11, e0164514. [CrossRef]

270. Tada, K.; Kitano, S.; Shoji, H.; Nishimura, T.; Shimada, Y.; Nagashima, K.; Aoki, K.; Hiraoka, N.; Honma, K.; Iwana, S.; et al. Pretreatment immune status correlates with pro-gression-free survival in chemotherapy- Treated metastatic colorectal cancer patients. Cancer Immunol. Res. 2016, 4, 592-599. [CrossRef]

271. Zhang, H.; Ye, Y.L.; Li, M.X.; Ye, S.B.; Huang, W.R.; Cai, T.T.; He, J.; Peng, J.-Y.; Duan, T.-H.; Cui, J.; et al. CXCL2/MIF-CXCR2 signaling promotes the recruitment of mye-loid-derived suppressor cells and is correlated with prognosis in bladder cancer. Oncogene 2017, 36, 2095-2104. [CrossRef]

272. Kawano, M.; Mabuchi, S.; Matsumoto, Y.; Sasano, T.; Takahashi, R.; Kuroda, H.; Kozasa, K.; Hashimoto, K.; Isobe, A.; Sawada, K.; et al. The significance of G-CSF expression and myeloid-derived suppressor cells in the chemoresistance of uterine cervical cancer. Sci. Rep. 2015, 5, 18217. [CrossRef]

273. Marini, O.; Spina, C.; Mimiola, E.; Cassaro, A.; Malerba, G.; Todeschini, G.; Perbellini, O.; Scupoli, M.; Carli, G.; Facchinelli, D.; et al. Identification of granulocytic myeloid-derived suppressor cells (G-MDSCs) in the peripheral blood of Hodgkin and non-Hodgkin lymphoma patients. Oncotarget 2016, 7, 27676-27688. [CrossRef] [PubMed]

274. Wang, Z.; Zhang, L.; Wang, H.; Xiong, S.; Li, Y.; Tao, Q.; Xiao, W.; Qin, H.; Wang, Y.; Zhai, Z. Tumor-induced CD14+HLA$\mathrm{DR}-/$ low myeloid-derived suppressor cells correlate with tumor progression and outcome of therapy in multiple myeloma patients. Cancer Immunol. Immunother. 2014, 64, 389-399. [CrossRef]

275. Wu, C.; Wu, X.; Zhang, X.; Chai, Y.; Guo, Q.; Li, L.; Yue, L.; Bai, J.; Wang, Z.; Zhang, L. Prognostic significance of peripheral monocytic myeloid-derived suppressor cells and monocytes in patients newly diagnosed with diffuse large b-cell lymphoma. Int. J. Clin. Exp. Med. 2015, 8, 15173-15181.

276. Talmadge, J.E.; Gabrilovich, D.I.; Immunology, T.T. History of myeloid derived suppressor cells (MDSCs) in the macro- and mi-cro-environment of tumour-bearing hosts. Nat. Rev. Cancer. 2013, 13, 739-752. [CrossRef] [PubMed]

277. Ostrand-Rosenberg, S.; Sinha, P. Myeloid-Derived Suppressor Cells: Linking Inflammation and Cancer. J. Immunol. 2009, 182, 4499-4506. [CrossRef] [PubMed]

278. Bunt, S.K.; Sinha, P.; Clements, V.K.; Leips, J.; Ostrand-Rosenberg, S. Inflammation Induces Myeloid-Derived Suppressor Cells that Facilitate Tumor Progression. J. Immunol. 2005, 176, 284-290. [CrossRef] [PubMed]

279. Sander, L.E.; Sackett, S.D.; Dierssen, U.; Beraza, N.; Linke, R.P.; Muller, M.; Blander, J.M.; Tacke, F.; Trautwein, C. Hepatic acute-phase proteins control innate immune responses during infection by promoting myeloid-derived suppressor cell function. J. Exp. Med. 2010, 207, 1453-1464. [CrossRef]

280. Cuenca, A.G.; Delano, M.J.; Kelly-Scumpia, K.M.; Moreno, C.; Scumpia, P.O.; LaFace, D.M.; Heyworth, P.G.; Efron, P.A.; Moldawer, L.L. A Paradoxical Role for Mye-loid-Derived Suppressor Cells in Sepsis and Trauma. Mol. Med. 2011, 17, 281-292. [CrossRef]

281. Loftus, T.; Mohr, A.; Moldawer, L.L. Dysregulated myelopoiesis and hematopoietic function following acute physiologic insult. Curr. Opin. Hematol. 2018, 25, 37-43. [CrossRef]

282. Tai, L.H.; Alkayyal, A.A.; Leslie, A.L.; Sahi, S.; Bennett, S.; Tanese de Souza, C.; Baxter, K.; Angka, L.; Xu, L.; Kennedy, M.A.; et al. Phosphodiesterase- 5 inhibition reduces postop-erative metastatic disease by targeting surgery-induced myeloid derived suppressor cell-dependent inhibition of Natural Killer cell cytotoxicity. OncoImmunology 2018, 7, e1431082. [CrossRef]

283. Ma, X.; Wang, M.; Yin, T.; Zhao, Y.; Wei, X. Myeloid-Derived Suppressor Cells Promote Metastasis in Breast Cancer After the Stress of Operative Removal of the Primary Cancer. Front. Oncol. 2019, 9, 855. [CrossRef] [PubMed]

284. Xu, P.; He, H.; Gu, Y.; Wang, Y.; Sun, Z.; Yang, L.; Miao, C. Surgical trauma contributes to progression of colon cancer by downregulating CXCL4 and recruiting MDSCs. Exp. Cell Res. 2018, 370, 692-698. [CrossRef]

285. Wang, J.; Yang, L.; Yu, L.; Wang, Y.-Y.; Chen, R.; Qian, J.; Hong, Z.-P.; Su, X.-S. Surgery-induced monocytic myeloid-derived suppressor cells expand regulatory T cells in lung cancer. Oncotarget 2017, 8, 17050-17058. [CrossRef]

286. Yuan, L.; Xu, B.; Fan, H.; Yuan, P.; Zhao, P.; Suo, Z. Pre- and post-operative evaluation: Percentages of circulating myeloid-derived suppressor cells in rectal cancer patients. Neoplasma 2015, 62, 239-249. [CrossRef] [PubMed]

287. Sarhan, D.; Cichocki, F.; Zhang, B.; Yingst, A.; Spellman, S.R.; Cooley, S.; Verneris, M.R.; Blazar, B.R.; Miller, J.S. Adaptive NK Cells with Low TIGIT Expression Are Inherently Resistant to Myeloid-Derived Suppressor Cells. Cancer Res. 2016, 76, 5696-5706. [CrossRef]

288. Hoechst, B.; Voigtlaender, T.; Ormandy, L.; Gamrekelashvili, J.; Zhao, F.; Wedemeyer, H.; Lehner, F.; Manns, M.P.; Greten, T.F.; Korangy, F. Myeloid derived suppressor cells inhibit natural killer cells in patients with hepatocellular carcinoma via the NKp30 receptor. Hepatology 2009, 50, 799-807. [CrossRef] [PubMed] 
289. Li, H.; Han, Y.; Guo, Q.; Zhang, M.; Cao, X. Cancer-Expanded Myeloid-Derived Suppressor Cells Induce Anergy of NK Cells through Membrane-Bound TGF- $\beta 1$. J. Immunol. 2008, 182, 240-249. [CrossRef] [PubMed]

290. Bronte, V.; Brandau, S.; Chen, S.-H.; Colombo, M.P.; Frey, A.; Greten, T.F.; Mandruzzato, S.; Murray, P.J.; Ochoa, A.; OstrandRosenberg, S.; et al. Recommendations for myeloid-derived suppressor cell nomenclature and characterization standards. Nat. Commun. 2016, 7, 12150. [CrossRef] [PubMed]

291. Serafini, P.; Meckel, K.; Kelso, M.; Noonan, K.; Califano, J.; Koch, W.; Dolcetti, L.; Bronte, V.; Borrello, I. Phosphodiesterase-5 inhibition augments endogenous antitumor immunity by reducing myeloid-derived suppressor cell function. J. Exp. Med. 2006, 203, 2691-2702. [CrossRef]

292. Auer, R.C. NCT02998736:PERIOP-04 Phase Ib Trial of Perioperative Tadalafiland Influenza Vaccination in Cancer Patients Undergoing Major Surgical Resection of a Primary Abdominal Malignancy. Available online: https://clinicaltrials.gov/ct2 / show / record/NCT02998736 (accessed on 10 January 2021).

293. Stiff, A.; Trikha, P.; Mundy-Bosse, B.; McMichael, E.; Mace, T.A.; Benner, B.; Kendra, K.; Campbell, A.; Gautam, S.; Abood, D.; et al. Nitric oxide production by myeloid-derived sup-pressor cells plays a role in impairing Fc receptor-mediated natural killer cell function. Clin. Cancer Res. 2018, 24, 1891-1904. [CrossRef]

294. Opfermann, P.; Derhaschnig, U.; Felli, A.; Wenisch, J.; Santer, D.; Zuckermann, A.; Dworschak, M.; Jilma, B.; Steinlechner, B. A pilot study on reparixin, a CXCR1/2 antagonist, to assess safety and efficacy in attenuating ischaemia-reperfusion injury and inflammation after on-pump coronary artery bypass graft surgery. Clin. Exp. Immunol. 2015, 180, 131-142. [CrossRef]

295. Scholten, D.J.; Canals, M.; Maussang, D.; Roumen, L.; Smit, M.J.; Wijtmans, M.; De Graaf, C.; Vischer, H.F.; Leurs, R. Pharmacological modulation of chemokine re-ceptor function. Br. J. Pharmacol. 2012, 165, 1617-1643. [CrossRef]

296. Xing, Y.-F.; Zhou, Y.-Q.; Ma, G.-W.; Feng, D.-Y.; Cai, X.-R.; Li, X. Issues with anti-Gr1 antibody-mediated myeloid-derived suppressor cell depletion. Ann. Rheum. Dis. 2016, 75, e49. [CrossRef] [PubMed]

297. Ostrand-Rosenberg, S.; Fenselau, C. Myeloid-Derived Suppressor Cells: Immune-Suppressive Cells That Impair Antitumor Immunity and Are Sculpted by Their Environment. J. Immunol. 2018, 200, 422-431. [CrossRef] [PubMed]

298. Budhwar, S.; Verma, P.; Verma, R.; Rai, S.; Singh, K. The Yin and Yang of Myeloid Derived Suppressor Cells. Front. Immunol. 2018, 9, 2776. [CrossRef] [PubMed]

299. Liu, D.; Sun, X.; Du, Y.; Kong, M. Propofol Promotes Activity and Tumor-Killing Ability of Natural Killer Cells in Peripheral Blood of Patients with Colon Cancer. Med. Sci. Monit. 2018, 24, 6119-6128. [CrossRef]

300. Ai, L.; Wang, H. Effects of propofol and sevoflurane on tumor killing activity of peripheral blood natural killer cells in patients with gastric cancer. Int. J. Med. Res. 2020, 48, 0300060520904861. [CrossRef] [PubMed]

301. Huang, H.; Benzonana, L.L.; Zhao, H.; Watts, H.R.; Perry, N.J.S.; Bevan, C.L.; Brown, R.; Ma, D. Prostate cancer cell malignancy via modulation of HIF-1 $\alpha$ pathway with isoflurane and propofol alone and in combination. Br. J. Cancer 2014, 111, 1338-1349. [CrossRef]

302. Lim, J.-A.; Oh, C.-S.; Yoon, T.-G.; Lee, J.Y.; Lee, S.-H.; Yoo, Y.-B.; Yang, J.-H.; Kim, S.-H. The effect of propofol and sevoflurane on cancer cell, natural killer cell, and cytotoxic T lymphocyte function in patients undergoing breast cancer surgery: An in vitro analysis. BMC Cancer 2018, 18, 159. [CrossRef]

303. Tazawa, K.; Koutsogiannaki, S.; Chamberlain, M.; Yuki, K. The effect of different anesthetics on tumor cytotoxicity by natural killer cells. Toxicol. Lett. 2016, 266, 23-31. [CrossRef]

304. Cho, J.S.; Lee, M.-H.; Kim, S.I.; Park, S.; Park, H.S.; Oh, E.; Lee, J.H.; Koo, B.-N. The Effects of Perioperative Anesthesia and Analgesia on Immune Function in Patients Undergoing Breast Cancer Resection: A Prospective Randomized Study. Int. J. Med Sci. 2017, 14, 970-976. [CrossRef]

305. Markovic, S.N.; Knight, P.R.; Murasko, D.M. Inhibition of Interferon Stimulation of Natural Killer Cell Activity in Mice Anesthetized with Halothane or Isoflurane. Anesthesiology 1993, 78, 700-706. [CrossRef]

306. Ma, D.; Lim, T.; Xu, J.; Tang, H.; Wan, Y.; Zhao, H.; Hossain, M.; Maxwell, P.H.; Maze, M. Xenon Preconditioning Protects against Renal Ischemic-Reperfusion Injury via HIF-1 $\alpha$ Activation. J. Am. Soc. Nephrol. 2009, 20, 713-720. [CrossRef]

307. Divatia, J.V. NCT03005860: Effect of TIVA Propofol vs. Sevoflurane Anaesthetic on Serum Biomarkers and on PBMCs in Breast Cancer Surgery; Wiley: Hoboken, NJ, USA, 2016.

308. Shavit, Y.; Ben-Eliyahu, S.; Zeidel, A.; Beilin, B. Effects of fentanyl on natural killer cell activity and on resistance to tumor metastasis in rats: Dose and timing study. Neuroimmunomodulation 2004, 11, 255-260. [CrossRef]

309. Desmond, F.; McCormack, J.; Mulligan, N.; Stokes, M.; Buggy, D.J. Effect of anaesthetic technique on immune cell infiltration in breast cancer: A follow-up pilot analysis of a prospective, randomised, investigator-masked study. Anticancer. Res. 2015, 35, 1311-1319. [PubMed]

310. Zhang, Z.; Chen, F.; Shang, L. Advances in antitumor effects of NSAIDs. Cancer Manag. Res. 2018, 10, 4631-4640. [CrossRef] [PubMed]

311. Zappavigna, S.; Cossu, A.M.; Grimaldi, A.; Bocchetti, M.; Ferraro, G.A.; Nicoletti, G.F.; Filosa, R.; Caraglia, M. Anti-Inflammatory Drugs as Anticancer Agents. Int. J. Mol. Sci. 2020, 21, 2605. [CrossRef] [PubMed]

312. Tartter, P.I. Immunologic Effects of Blood Transfusion. Immunol. Investig. 1995, 24, 277-288. [CrossRef]

313. Youssef, L.A.; Spitalnik, S.L. Transfusion-related immunomodulation: A reappraisal. Curr. Opin. Hematol. 2017, 24, 551. [CrossRef] 
314. Jensen, L.S.; Andersen, A.J.; Christiansen, P.M.; Hokland, P.; Juhl, C.O.; Madsen, G.; Mortensen, J.; Meller-Nielsen, C.; HanbergSørensen, F. Postoperative infection and natural killer cell function following blood transfusion in patients undergoing elective colorectal surgery. Br. J. Surg. 1992, 79, 513-516. [CrossRef]

315. Ghio, M.; Contini, P.; Negrini, S.; Mazzei, C.; Zocchi, M.R.; Poggi, A. Down regulation of human natural killer cell-mediated cytolysis induced by blood transfusion: Role of transforming growth factor- $\beta 1$, soluble Fas ligand, and soluble Class i human leukocyte antigen. Transfusion 2011, 51, 1567-1573. [CrossRef]

316. Agnes, A.; Lirosi, M.C.; Panunzi, S.; Santocchi, P.; Persiani, R.; D’Ugo, D. The prognostic role of perioperative allogeneic blood transfusions in gastric cancer patients undergoing curative resection: A systematic review and meta-analysis of non-randomized, adjusted studies. Eur. J. Surg. Oncol. (EJSO) 2018, 44, 404-419. [CrossRef]

317. Li, S.-L.; Ye, Y.; Yuan, X.-H. Association between Allogeneic or Autologous Blood Transfusion and Survival in Patients after Radical Prostatectomy: A Systematic Review and Meta-Analysis. PLoS ONE 2017, 12, e0171081. [CrossRef]

318. Wang, F.; Liu, H.; Wang, F.; Xu, R.; Wang, P.; Tang, F.; Zhang, X.; Zhu, Z.; Lv, H.; Han, T. Propranolol suppresses the proliferation and induces the apoptosis of liver cancer cells. Mol. Med. Rep. 2018, 17, 5213-5221. [CrossRef] [PubMed]

319. Cata, J.P.; Lasala, J.; Pratt, G.; Feng, L.; Shah, J.B. Association between Perioperative Blood Transfusions and Clinical Outcomes in Patients Undergoing Bladder Cancer Surgery: A Systematic Review and Meta-Analysis Study. J. Blood Transfus. 2016, 2016, 1-8. [CrossRef]

320. Reeh, M.; Ghadban, T.; Dedow, J.; Vettorazzi, E.; Uzunoglu, F.G.; Nentwich, M.F.; Kluge, S.; Izbicki, J.R.; Vashist, Y.K. Allogenic Blood Transfusion is Associated with Poor Perioperative and Long-Term Outcome in Esophageal Cancer. World J. Surg. 2016, 41, 208-215. [CrossRef]

321. Amato, A.; Pescatori, M. Perioperative blood transfusions and recurrence of colorectal cancer. Cochrane Database Syst. Rev. 2006, 1. [CrossRef]

322. Gharehbaghian, A.; Haque, K.M.; Truman, C.; Evans, R.; Morse, R.; Newman, J.; Bannister, G.; Rogers, C.; Bradley, B.A. Effect of autologous salvaged blood on postoperative natural killer cell precursor frequency. Lancet 2004, 363, 1025-1030. [CrossRef] 